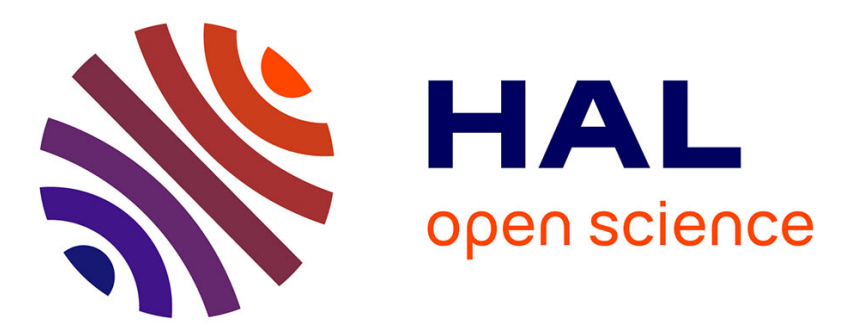

\title{
Imprint of seasonality changes on fluvio-glacial dynamics across Heinrich Stadial 1 (NE Atlantic Ocean)
}

\author{
Wiem Fersi, Aurélie Penaud, Mélanie Wary, Samuel Toucanne, Claire
}

Waelbroeck, Linda Rossignol, Frédérique Eynaud

\section{- To cite this version:}

Wiem Fersi, Aurélie Penaud, Mélanie Wary, Samuel Toucanne, Claire Waelbroeck, et al.. Imprint of seasonality changes on fluvio-glacial dynamics across Heinrich Stadial 1 (NE Atlantic Ocean). Global and Planetary Change, 2021, 204, pp.103552. 10.1016/j.gloplacha.2021.103552 . hal-03455758v1

\section{HAL Id: hal-03455758 \\ https://hal.science/hal-03455758v1}

Submitted on 30 Nov 2021 (v1), last revised 15 Dec 2021 (v2)

HAL is a multi-disciplinary open access archive for the deposit and dissemination of scientific research documents, whether they are published or not. The documents may come from teaching and research institutions in France or abroad, or from public or private research centers.
L'archive ouverte pluridisciplinaire HAL, est destinée au dépôt et à la diffusion de documents scientifiques de niveau recherche, publiés ou non, émanant des établissements d'enseignement et de recherche français ou étrangers, des laboratoires publics ou privés. 
1 Imprint of seasonality changes on fluvio-glacial dynamics across

\section{Heinrich Stadial 1 (NE Atlantic Ocean)}

3

4 5

6

7

8

9

Wiem Fersi ${ }^{(a)}$, Aurélie Penaud ${ }^{(a)}$, Mélanie Wary ${ }^{(b)}$, Samuel Toucanne ${ }^{(c)}$, Claire Waelbroeck $^{(\mathrm{d})}$, Linda Rossignol ${ }^{(\mathrm{e})}$, Frédérique Eynaud ${ }^{(\mathrm{e})}$

(a) Univ Brest (UBO), CNRS, UMR 6538 Laboratoire Géosciences Océan (LGO), F29280 Plouzané, France

(b) Institut de Ciència i Tecnologia Ambientals (ICTA-UAB), Universitat Autònoma de Barcelona, Bellaterra, Catalonia, Spain

(c) Ifremer, Laboratoire Géophysique et environnements Sédimentaires. F-29280 Plouzané, France

(d) LOCEAN/IPSL, Sorbonne Université-CNRS-IRD-MNHN, UMR7159, Paris, France

(e) Univ Bordeaux, CNRS, UMR 5805 Environnements et Paléoenvironnements Océaniques et Continentaux (EPOC), F-33405 Talence, France

*Corresponding author. Tel.: +33-298-498-741; fax: +33-298-498-760.

E-mail addresses: wiem.fersi@univ-brest.fr, aurelie.penaud@univ-brest.fr 


\section{Abstract}

22 The northern Bay of Biscay has previously proven its great potential for recording the 'Fleuve Manche' paleoriver (i.e., the largest Pleistocene river in Europe) fluvio-glacial activity. In this study, new dinoflagellate cyst (dinocyst) analyses have been carried out at sub-centennial resolution in core MD13-3438 to reconstruct the deglacial history of the 'Fleuve Manche' paleoriver runoff coupled with European Ice Sheets (EIS) fluctuations across Heinrich Stadial

271 (HS1: 18.2-14.6 ka BP), a key extreme climatic event of the last glacial period. Prior to 28 Heinrich Event (HE) 1 (16.7-14.6 ka BP), the onset of HS1 (18.2-16.7 ka BP) appears here marked by enhanced 'Fleuve Manche' paleoriver runoff, materialized by laminated deposits. Our work suggests a novel sub-centennial scale subdivision of the early HS1 (laminated) interval into 5 sub-phases when episodes of substantial fluvio-glacial delivery concomitant with warm summers alternate with episodes of moderate runoff associated with extended cold winters. We argue that multidecadal seasonal changes played a key role in the hydrological regime of western Europe during this HS1 interval, with the retreat of the southern limb of the EIS, and associated influx of meltwater and fluvio-glacial delivery, which were strongly influenced by those multidecadal changes in seasonality. Interestingly, our paleoclimatic record not only evidences the crucial role of seasonality in controlling climate and hydrological variations during HS1 but also shows a remarkable echo with reconstructions from the western Mediterranean Basin, highlighting common climate forcings at regional 40 scale during the last deglaciation.

41 Keywords: Heinrich Stadial 1; Dinoflagellate cysts; northern Bay of Biscay; 'Fleuve Manche' paleoriver; European Ice Sheets 


\section{Introduction}

The last glacial period was accompanied by millennial-scale abrupt climate shifts, portrayed in Greenland ice-cores as rapid transitions from cold atmospheric phases termed Greenland Stadials (GS) to warm atmospheric phases referred to as Greenland Interstadials (GI; e.g., Dansgaard et al., 1993; Rasmussen et al., 2014). Despite their original designation, these climate excursions had an impact across the globe (e.g., Voelker, 2002). In the North Atlantic Ocean, some GS were associated with massive iceberg surges mainly from the Laurentide Ice Sheet (LIS) via the Hudson Strait Ice Stream (e.g., Bond et al., 1992, 1993; Broecker et al., 1992, 1994; Hemming, 2004), identified in marine sediments as Ice Rafted Debris (IRD)enriched layers (e.g., Bond et al., 1993; Broecker, 1994; Heinrich, 1988). These massive iceberg(and thus freshwater) surge events are known as Heinrich Events (HEs including HE1), with their corresponding stadial phases called Heinrich Stadials (HSs including HS1; Barker et al., 2009; Sanchez Goñi and Harrison, 2010). The associated huge freshwater releases resulted in large reductions of the Atlantic Meridional Overturning Circulation (AMOC; e.g., McManus et al., 2004; Stanford et al., 2006, 2011; Ng et al., 2018; Toucanne et al., 2021). Numerous studies demonstrated that Greenland Iceland and European Ice Sheets were also major contributors to the oceanic disturbances in the North Atlantic Ocean, especially when considering the surge sequencing along time (e.g., Bond et al., 1997, 1999; Grousset et al., 2000, 2001; Hemming et al., 2000, 2004; Knutz et al., 2001, 2007; Hall et al., 2006; Peck et al., 2006; Nygård et al., 2007; Toucanne et al., 2008, 2010, 2015).

HS1, including the HE1 layer, occurred at the onset of the last deglaciation ( 19-11 ka BP; Clark et al., 2012a), just before the abrupt Bølling-Allerød (B/A) warming event starting at ca. 14.7 ka BP (Rasmussen et al., 2014) and after the Last Glacial Maximum (LGM; Mix et al., 2001). Over the LGM, which was characterized by a large European Ice Sheet (EIS) including the British-Irish (BIIS) and Scandinavian (SIS) Ice Sheets, the 'Fleuve Manche' paleoriver (Channel River) was one of the largest river systems that drained western Europe (e.g., Gibbard, 1988; Toucanne et al., 2009, 2010, 2015). This huge fluvial system included the French, Belgian and British rivers, and the merged German, Polish and Dutch rivers, on the exposed English Channel and North Sea Basin, respectively. Multiproxy studies conducted along the northwestern European margin and especially from the northern Bay of Biscay (e.g., Zaragosi et al., 2001; Auffret et al., 2002; Mojtahid et al., 2005, 2017; Eynaud et al., 2007, 2012; Penaud et al., 2009; Toucanne et al., 2009, 2010), identified recurrent phases of meltwater inputs at the onset of HS1 (between 18.3 and $17 \mathrm{ka}$ BP). Materialized in sediments 
as millimeter- to centimeter-scale laminations, they were attributed to the seasonal melting of the EIS and seasonal subsequent freshwater discharge from the 'Fleuve Manche' paleoriver. Further works provided new evidence of a differential contribution from ice sheets to the laminated deposit, with a particularly large SIS/Baltic sourced part during the last deglaciation and the HS1 interval (Toucanne et al., 2015). Until now, palynological investigation of this laminated facies (Eynaud, 1999, 2007, 2012; Auffret et al., 2000; Zaragosi et al., 2001; Penaud et al., 2009) was performed at resolution varying between 70 and 250 years only, due to the strong dilution of palynomorphs in sediments. Such laminated facies, corresponding to exceptionally high sedimentation rates, appear as ideal candidates to increase the temporal resolution of marine records and thus improve our understanding of short-lived fluctuations in the regime of the 'Fleuve Manche' paleoriver and associated EIS dynamics.

89 Our study thus constitutes the first detailed dinocyst study encompassing the HS1 interval in 90 the Bay of Biscay with a special focus on the laminated facies deposited at the onset of HS1.

91 Our main objective was to decipher the set and sequence of events that occurred during this period over the northern Bay of Biscay. Our high-resolution palynological study was conducted on core MD13-3438 and combined with micropaleontological, geochemical and sedimentological analyses available for the twin reference core MD95-2002. Our multiproxy approach led to:

96 (1) the reconstruction of the coupled EIS and 'Fleuve Manche' paleoriver dynamics across 97 HS1;

98 (2) the study of high frequency seasonal variability within the laminated deposit, providing 99 the first reconstruction of the sub-centennial climate variability across HS1 in the NE 100 Atlantic;

101 (3) and the characterization of sea surface conditions over the northern Bay of Biscay using 102 dinocyst quantifications (keeping in mind their potentialities and limits in the study area). 


\section{Environmental context}

104

105

106

107

108

109

110

111

112

113

114

115

116

117

118

119

120

121

122

123

124

125

126

127

128

129

130

131

132

133

\subsection{Location of the studied core}

The Calypso long piston core MD13-3438 (472 $27^{\prime} \mathrm{N} ; 8^{\circ} 27^{\prime} \mathrm{W} ; 2180 \mathrm{~m}$ water depth; $36 \mathrm{~m}$ long) and twin core MD95-2002 (47 $27^{\prime} \mathrm{N} ; 8^{\circ} 32^{\prime} \mathrm{W} ; 2174 \mathrm{~m}$ water depth) were respectively collected during the VT 133 / MERIADZEK (Woerther, 2013) and MD101-IMAGES (Bassinot and Labeyrie, 1996) oceanographic cruises on board the R/V Marion Dufresne (Table 1).

These marine sedimentary archives were retrieved from the Meriadzek Terrace, northern Bay of Biscay, directly off the mouth of the 'Fleuve Manche' paleoriver (Fig. 1a). Their recovery, on a structure lying $600 \mathrm{~m}$ above the abyssal plain, guarantees few disturbances from gravity processes despite the proximity of deep-sea turbidite systems (Auffret et al., 2000; Zaragosi et al., 2000, 2001). The late Quaternary sedimentation of this area was imprinted by supplies from the northwestern European drainage catchments via the 'Fleuve Manche' paleoriver during glacial lowstands (Auffret et al., 2000; Bourillet et al., 2003; Mojtahid et al., 2005; Zaragosi et al., 2006; Eynaud et al., 2007; Toucanne et al., 2008, 2009).

At present, the water column is structured by the deep Labrador Sea Water $(\sim 1500-2000 \mathrm{~m}$ depth) characterized by salinity ranging from 35 to 35.5 psu (Cossa et al., 2004) and the intermediate warm and salty (35.7 psu) Mediterranean Outflow Water (800-1500 m depth). Down to $800 \mathrm{~m}$ depth, the modern European Slope Current carries warm and salty waters to the Nordic Seas (Berx et al., 2013). Surface waters over the study area correspond to the southward recirculation of the North Atlantic Current (NAC; Fig. 1a), i.e., the south-eastern branch of the subpolar North Atlantic gyre (e.g., Sutton and Allen, 1997; Daniault et al., 2016). At the study site, modern (i.e., pre- $21^{\text {st }}$ century) mean Sea Surface Temperature (SST) and Salinity (SSS) are $11.7 \pm 0.6{ }^{\circ} \mathrm{C}$ and $35.54 \pm 0.05 \mathrm{psu}$ in winter, and $17.5 \pm 1.0{ }^{\circ} \mathrm{C}$ and $35.58 \pm 0.10$ psu in summer (World Ocean Atlas, 2001; Conkright et al., 2002).

2.2. Climatic changes in the northern Bay of Biscay during the last 40 kyr with focus on HS1

A large number of studies have shown that core MD95-2002 (Fig. 1a) has archived the history of deglacial pulses and meltwater discharge from the EIS (Zaragosi et al., 2001; Ménot et al., 2006; Eynaud et al., 2007, 2012; Penaud et al., 2009; Toucanne et al., 2009, 2015; Fig. 1b). 
134 Data acquired on MD95-2002 (Fig. 1b) indeed provided nearshore marine to terrestrial 135 information (Table 1 for related references).

136 In the North Atlantic Ocean, HS can be recognized on the basis of Neogloboquadrina 137 pachyderma abundances close to 100\% (e.g., Broecker et al., 1992; Eynaud et al., 2009). At 138 site MD95-2002, HS1 (blue band on Fig. 1b) is thus identified as the interval between 18.2$13914.6 \mathrm{ka}$ BP (Fig. 1b). Early HS1 is evidenced by repeated alternation of millimeter- to 140 centimeter-scale deposits (i.e., laminae) of mud and Coarse Lithic Grains (CLG) (Zaragosi et 141 al., 2001). This facies results from an intense activity of the 'Fleuve Manche' paleoriver in 142 response to the substantial EIS retreat (e.g., Mojtahid et al., 2005; Zaragosi et al., 2006; 143 Eynaud et al., 2007; Toucanne et al., 2008). This laminated interval is associated with high 144 concentrations of the freshwater micro-algae Pediastrum (Penaud et al., 2009), high values of 145 the $\mathrm{Ti} / \mathrm{Ca}-\mathrm{XRF}$ ratio (i.e., detrital versus biogenic proxy for enhanced terrigenous supply; 146 Toucanne et al., 2009, 2012, 2015) and of the Branched and Isoprenoid Tetraether (BIT) 147 index (i.e., a proxy for the relative fluvial input of terrestrial organic matter in the marine 148 environment; Ménot et al., 2006). All those tracers highlight strong fluvial inputs and 149 terrestrial-sourced organic sediment advections over the northern Bay of Biscay. This period 150 is concomitant with major EIS melting events, especially from the Baltic Ice Stream of the 151 SIS, accompanied by seasonal spring-summer meltwater discharge into the Bay of Biscay 152 (Zaragosi et al., 2001; Mojtahid et al., 2005; Ménot et al., 2006; Eynaud et al., 2007, 2012; 153 Penaud et al., 2009; Toucanne et al., 2008, 2009, 2015). Within the laminated interval, the 154 concentrations of CLG (Fig.1b) include both, Laurentide and European-sourced IRDs and 155 also fluvial lithic grains transported via the 'Fleuve Manche' paleoriver. Increased CLG 156 concentrations then recorded between 16.7 and 15 ka BP (Fig.1b; Zaragosi et al., 2001) 157 characterize the HE1 phase. This interval contains the 'conventional' HE1 layer marked by 158 notable peaks of magnetic susceptibility and carbonates (low Ti/Ca values) at $\sim 16 \mathrm{ka} \mathrm{BP}$ 159 characterizing the typical LIS surge (Grousset et al., 2000; Toucanne et al., 2015; Fig.1b). 


\section{Material and methods}

162

163

164

165

166

167

168

169

170

171

172

173

174

175

176

177

178

179

180

181

182

183

184

185

186

187

188

189

190

191

\subsection{Stratigraphy of core MD13-3438}

The age model of core MD13-3438 is wedged on the last updated chronostratigraphy of core MD95-2002 (Toucanne et al., 2015). This latter was built with the Clam software (Blaauw, 2010) by integrating 22 AMS- ${ }^{14} \mathrm{C}$ dates over the last $40 \mathrm{kyr}$ with additional tie-points: (i) 4 AMS- ${ }^{14} \mathrm{C}$ dates tied from the neighbouring cores MD03-2690 and MD03-2692, and (ii) $N$. pachyderma abundances correlated with the NGRIP $\delta^{18} \mathrm{O}$ signal. Modern reservoir age correction is estimated to about $352 \pm 92$ years. Prior to HS1 and during the Holocene, the reservoir age constantly averaged around $400 \pm 200{ }^{14} \mathrm{C}$ years. During HS1, the B/A and the Younger Dryas, average reservoir ages were respectively estimated to about 970, 680 and 875 years with uncertainties of 200 years (1s) (Toucanne et al., 2015).

The age model of core MD13-3438 was established by the correlation of its Ti/Ca-XRF signal with that of its twin core MD95-2002 (Fig. 1b). The XRF analysis of core MD13-3438 was performed at Ifremer (Plouzané) using an Avaatech X-Ray Fluorescence core scanner at 1 cm-resolution. Tie points used to synchronize both Ti/Ca-XRF signals can be found in Table 2. The correlation is supported by planktonic foraminiferal data (counts of the total assemblage performed on the $>150 \mu \mathrm{m}$ sediment fraction and on $>300$ individuals for each sample at EPOC laboratory), especially the high $N$. pachyderma relative abundances delimiting the HS1 interval (Fig. 1b). Our $5 \mathrm{~cm}$-sampling frequency for dinocyst analyses enables us to achieve a temporal resolution of about 18 to 186 years, with a mean resolution of 58 years in all the studied sections, and of about 29 years in the laminated sequence, characterized by sedimentation rate values around $185 \mathrm{~cm} / \mathrm{kyr}$ (Fig. 1b). This resolution thus provides valuable new details on the deglacial climatic history of the northern European margin across the HS1 interval.

It is worth noting that recent studies showed that the rapid cooling marking the onset of HS1 in the North Atlantic took place at $17.48 \mathrm{ka} \pm 0.21 \mathrm{ka}(1 \sigma)$ (Missiaen et al., 2019; Waelbroeck et al., 2019) while maximal N. pachyderma abundances (i.e., allowing identifying HS 1) in core MD95-2002 between 880-390 cm, and between 575-245 cm in core MD13-3438, start at around $18.2 \mathrm{ka}$ BP (Fig. 1b). Our chronologies are likely too old by about 700 years at the onset of HS1 as a result of underestimated reservoir ages over the last deglaciation. 


\subsection{Dinocyst analyses}

194 a. Laboratory procedure, dinoflagellate cyst identification and diversity indices

195 A total of 76 samples were analysed from the 18.4-14 ka BP interval encompassing HS1.

196 Palynological treatments were performed at EPOC laboratory (University of Bordeaux,

197 France) following a standard protocol described by de Vernal et al. (1999). Calibrated tablets

198 of known concentrations of Lycopodium clavatum spores were added to each sample before

199 chemical treatments in order to estimate palynomorph concentrations. Chemical treatments

200 include cold $\mathrm{HCl}$ (10\%), cold $\mathrm{HF}$ (40 and 70\%) and sieving through single-use $10 \mu \mathrm{m}$ nylon

201 mesh screens. For each sample, an average of about 400 specimens (minimal counts of 175

202 cysts) was achieved using a Leica DM 2500 microscope at $\times 630$ magnification except for the

203 laminated sequence between 575 and $330 \mathrm{~cm}$ for which an average of 120 specimens

204 (minimal counts of 100 cysts) was obtained due to strong dilution.

205 Dinocyst ecology has been thoroughly described through the progressive development and 206 compilation of atlases of modern cyst distribution (Matthiessen, 1995; Rochon et al., 1999; 207 Marret and Zonneveld, 2003; Zonneveld et al., 2013; van Nieuwenhove et al., 2020; Marret et 208 al., 2020). For this study, taxonomic attribution and the grouping of some species were done 209 in accordance with those atlases. Brigantedinium spp. taxa include all spherical brown cysts 210 excluding Dubridinium spp. Other peridinioid cysts were grouped (i.e., Quinquecuspis spp., 211 Lejeunecysta spp., Dubridinium spp. and Votadinium spp.) as miscellaneous peridinioid cysts 212 (MPCs). Dinocyst assemblages were described with the relative abundances of each taxon 213 calculated on the basis of the total sum of specimens counted including unidentified taxa and 214 excluding pre-Quaternary cysts. Finally, the species richness and Margalef index (Harper, 215 1999), calculated using PAST v.1.75b (Hammer et al., 2001), have been used to estimate the 216 dinocyst assemblage diversity as an additional ecological indicator. The species richness 217 represents the number of different taxa identified within each studied sample. The Margalef 218 diversity index (Margalef, 1958) is defined by: Margalef's Index $=(\mathrm{S}-1) / \ln (\mathrm{N})$, where $\mathrm{S}$ 219 and $\mathrm{N}$ correspond to the total number of species $(\mathrm{S})$ and of individuals $(\mathrm{N})$ in the sample.

221 b. Dinoflagellate cyst ratios and fluvial-derived palynological tracers

222 A "Warm/Cold" (W/C) ratio (Table 3) was used to qualitatively address SST variations 223 (Turon and Londeix, 1988; Versteegh, 1994; Combourieu- Nebout et al., 1999; Eynaud et al., 224 2016; Penaud et al., 2016). Also, the "Heterotrophic/Autotrophic" (H/A) ratio (Table 3) was 
calculated. This ratio is often used to discuss changes in primary productivity (PP) since heterotrophic dinoflagellates have a strict heterotrophic strategy of nutrition, being indirectly related to food resources, especially diatoms (Wall et al., 1977; Lewis et al., 1990; Marret, 1994; Zonneveld et al., 1997, 2001, 2013). It is worth noting that a large part of gonyaulacoids cysts (phototrophic cyst producing taxa) may survive thousands of years in well oxygenated sediments but heterotrophic peridinioids are extremely sensitive and vulnerable to early diagenesis. Since availability of oxygen in the sediments is the most important diagenetic variable, it has been suggested that the amount of species-selective degradation (i.e., here calculated as the $\mathrm{H} / \mathrm{A}$ ratio for instance) may also be related to bottom water oxygen concentration, itself related to the rate of deep-ocean ventilation (Zonneveld et al., 2008). Both PP and/or taphonomic issues have to be taken into account to fully understand the $\mathrm{H} / \mathrm{A}$ ratio.

The "Lingulodinium machaerophorum / Operculodinium centrocarpum" (Lmac/Ocen) ratio was used to discuss continental versus oceanic influences at the core location (e.g., Penaud et al., 2020), L. machaerophorum being a taxon dominating (nearly monospecifically) in estuarine environments of the French Atlantic coast (Wall et al., 1977; Morzadec-Kerfourn, 1977; Ganne et al., 2016; Lambert et al., 2017). Finally, a new ratio “L. machaerophorum / Islandinium minutum" (Lmac/Imin) has been used in this study as a proxy for summer versus winter prevailing seasonality modes. I. minutum is abundant in polar regions where surface waters do not exceed $0{ }^{\circ} \mathrm{C}$ in winter (Zonneveld et al., 2013). In addition, pre-Quaternary dinocysts and Non Pollen Palynomorphs (NPP) including freshwater micro-algae Pediastrum spp. coenobia, Botryococcus spp. and Concentricystes spp.) were counted on the same palynological slides and expressed in absolute concentrations (palynomorphs $/ \mathrm{cm}^{3}$ ). It has been demonstrated that Pediastrum spp. freshwater micro-algae are related to strong river discharge in marine environments (Zaragosi et al., 2001; Lézine et al., 2005; Eynaud et al., 2007; Penaud et al., 2009). Also, the biostratigraphical study of Kaiser (2001, unpublished data), based on the identification of reworked dinocysts in core MD95-2002 revealed that they were derived from the second half of the Mesozoic (Late Jurassic) to the Early Tertiary (Miocene), then characterizing the Manche, Parisian Basin and South England geological formations. Therefore, concentrations of Pediastrum spp. microalgae and pre-Quaternary dinocysts, together with the ratio of "Reworked" (Rd, preQuaternary) versus "Modern" (Md) dinocysts (i.e., $\mathrm{Rd} / \mathrm{Md}$ ratio), constitute robust proxies to discuss 'Fleuve Manche' paleoriver discharge in the Bay of Biscay (e.g., Zaragosi et al., 
and Pediastrum spp. concentrations, together with L. machaerophorum occurrences and the

260 Lmac/Ocen ratio will be referred to as Fluvial-derived Palynological Tracers (FPT) allowing 261 discussing fluvio-glacial delivery to the NW European margin.

263 c. Dinocyst-based quantitative reconstructions of sea-surface parameters

264 The Modern Analogue Techniques (MAT), run on the "R version 2.7.0" software (R 265 Development Core Team, 2008; http://www.r-project.org/), was applied on dinocyst 266 assemblages to estimate past quantitative sea-surface environmental parameters. The MAT 267 consists in the comparison of fossil records with modern dinocyst assemblages from the most 268 recent update of the standardized Northern Hemisphere "modern" dinocyst database, which 269 includes the abundance of 71 different taxa and 1968 sites in relation to 17 modern 270 environmental parameters (de Vernal et al., 2020). This method relies on the assumption that 271 modern relationships between hydrographical parameters and dinocyst assemblages were still 272 valid in the past (e.g., Guiot and de Vernal, 2007). Sources of uncertainties, quantified with 273 the Root Mean Square Errors (RMSE), could derive from the lack of modern analogues 274 corresponding to fossil assemblages (Guiot and de Vernal, 2007; de Vernal et al., 2020).

275 The quantification of hydrological parameters is based on a weighted average of the values 276 obtained for the five best modern analogues, with the maximum weight being given to the 277 statistically closest analogue. Regarding the threshold distance $\left(\mathrm{d}_{\mathrm{T}}=1.2\right)$, analogues are i) good 278 when the distance $\mathrm{d}<\mathrm{d}_{\mathrm{T}} / 2$, ii) acceptable when $\mathrm{d}_{\mathrm{T}} / 2<\mathrm{d}<\mathrm{d}_{\mathrm{T}}$, and iii) poor when $\mathrm{d}>\mathrm{d}_{\mathrm{T}}$ (de 279 Vernal et al., 2005). The $\mathrm{n}=1968$ database and its related environmental database, allows the 280 reconstruction of summer and winter SST and SSS, mean annual Primary Productivity (PP), 281 and Sea Ice Cover Duration $\left(\mathrm{SIC}_{\mathrm{D}}\right)$, with RMSE of $\pm 1.8{ }^{\circ} \mathrm{C}$ for $\mathrm{SST}_{\text {summer }} \pm 1.2^{\circ} \mathrm{C}$ for $282 \mathrm{SST}_{\text {winter }} \pm 2.1 \mathrm{psu}$ for $\mathrm{SSS}_{\text {summer }} \pm 1.1 \mathrm{psu}$ for $\mathrm{SSS}_{\text {winter, }} \pm 138 \mathrm{gC} \mathrm{m}^{-2}$ for $\mathrm{PP}$ annual, \pm 1.5 283 months year ${ }^{-1}$ for $\mathrm{SIC}_{\mathrm{D}}$. 


\section{Palynological results}

286 Based on a cluster analysis run on dinocyst taxa percentages with the Psimpoll program, 9 287 palynozones were identified in core MD13-3438. We labelled them according to the 288 stratigraphic interval they match: LGM $(595-578 \mathrm{~cm})$, HS1-a as the onset of HS1 prior to 289 HE1 - HS1-a being subdivided into 5 sub-palynozones termed HS1-a1 to HS1-a5 (578-330 $290 \mathrm{~cm})$, and HS1-b $(330-270 \mathrm{~cm})$ and HS1-c $(270-240 \mathrm{~cm})$ as the first and second phase of HE1, 291 respectively. Palynological data are presented and discussed according to these palynozones. 292 They are plotted versus depth (cm) in result figures (Figs. 2 to 4), to exhibit the regularly 293 sampled data without considering the strong impact of sedimentation rates, and then versus 294 age (Cal ka BP) in the discussion figures (Figs. 5 to 7).

4.1. Quaternary dinocyst and other palynomorph abundances and derived indices

a. General observations on MD13-3438 results

A total of 31 different Quaternary dinocyst taxa (autotrophic or heterotrophic) have been identified (Table 3) with a species richness of about 15 different taxa per slide varying between 7 taxa at $580 \mathrm{~cm}$ and 25 taxa at $240 \mathrm{~cm}$ (Fig. 2). The Margalef index strongly matches the species richness with a general increasing trend from the bottom to the top of the studied section (Fig. 2), diversity being the lowest during the end of the LGM. Quaternary dinocyst concentrations vary from about 1200 to 47600 cysts $/ \mathrm{cm}^{3}$, with average values of 5200 cysts $/ \mathrm{cm}^{3}$ (Fig. 3). Overall, dinocyst assemblages are dominated by heterotrophic taxa (mean value of 57\%) including especially Brigantedinium spp. (30\%) and miscellaneous peridinioid cysts (MPCs) (21\%), as well as Islandinium minutum (3\%), cysts of Protoperidinium nudum grouped with Selenopemphix quanta (1\%) as well as Echinidinium spp. (2\%; Fig. 3). The H/A ratio trend (Fig. 2) seems to be mainly explained by fluctuations in Brigantedinium spp. (Fig. 2). The lowest values of this ratio are observed across the LGM, followed by high to moderate values across HS1-a and by a decreasing trend from the start of

312 HS1-b to the onset of the B/A. Autotrophic taxa (mean value of 43\%) are dominated by the 313 following species: Operculodinium centrocarpum (16\%), Bitectatodinium tepikiense (9\%), 314 Lingulodinium machaerophorum (4\%), cysts of Pentapharsodinium dalei (3\%), 315 Nematosphaeropsis labyrinthus (3\%), Spiniferites lazus (2\%), Spiniferites ramosus (2\%) 316 Spiniferites belerius (2\%) and Spiniferites septentrionalis (2\%) (Fig. 3). 
318 b. Detailed observations according to the 9 palynozones

319 Each of the 9 palynozones can be described in terms of Quaternary dinocyst percentages, 320 which they were statistically established from, but also in terms of other micropaleontological 321 indicators. They are labelled from LGM to B/A (Fig. 2, Fig. 3):

322 - LGM: This lowermost zone exhibits the highest dinocyst concentrations (10000 to 47000 323 cysts $/ \mathrm{cm}^{3}$ ) explained by maximal values of $O$. centrocarpum occurrences (higher than $85 \%$ ). $324 N$. pachyderma percentages show relatively low values (lower than 22\%).

325 - HS1-a: The transition between LGM and HS1-a is marked by an abrupt decrease of $O$. 326 centrocarpum percentages and the increase of heterotrophic taxa (Brigantedinium ssp. and 327 MPCs) representing more than $60 \%$ of the total cyst assemblages until $330 \mathrm{~cm}$. Also, this 328 interval is characterized by increasing $N$. pachyderma percentages. Five sub-zones have been 329 distinguished: Sub-zone HS1-a1 corresponds to the first evidence of increasing FPT values 330 and shows higher percentages of B. tepikiense, Brigantedinium spp. as well as MPCs. In sub331 zone HS1-a2, B. tepikiense percentages decrease while a diversification of the assemblage is 332 observed, with especially higher relative abundances of Spiniferites spp., L. machaerophorum 333 and cysts of $P$. dalei, while Quaternary dinocyst concentrations are the highest of the whole 334 HS1-a interval. Importantly, concentrations of reworked cysts and of total freshwater micro335 algae show maximal values during this HS1-a2 sub-zone (Fig. 2). Dinocyst concentrations 336 reach minimal values $\left(2500 \mathrm{cyst} / \mathrm{cm}^{3}\right)$ within HS1-a3, HS1-a4 and HS1-a5, when important 337 increases of MPCs are also recorded. While HS1-a3 is characterized by the dominance of 338 Brigantedinium spp., $\mathrm{HS} 1-\mathrm{a} 4$ and $\mathrm{HS1-a5}$ are marked by maximal values of $L$. 339 machaerophorum (16\%) and the highest Lmac/Ocen values. A second peak of freshwater 340 micro-algae concentrations associated with maximal values of $\mathrm{Rd} / \mathrm{Md}$ ratio additionally 341 characterises HS1-a4 (Fig. 2). I. minutum abundances increase from the beginning of HS1-a5 342 at $360 \mathrm{~cm}$ concomitantly with decreasing FPT values (Fig. 2, Fig. 3).

343 - HS1-b: This interval is generally characterized by a strong drop of MPCs with low to near344 zero values persisting all the way up to the top of the studied interval, and the gradual decline 345 of L. machaerophorum percentages. Maximal values of I. minutum (maximum about 20\%) 346 and S. septentrionalis (maximum about $6 \%$ ) occur in this zone.

347 - HS1-c: This interval is characterized by higher percentages of $O$. centrocarpum (20\%), B. 348 tepikiense (18\%), and Echinidinium spp. (10\%), while I. minutum and L. machaerophorum 349 strongly decrease and are nearly absent until the end of the studied sequence. 
- B/A: This interval is marked by the significant drop of $N$. pachyderma percentages from $\sim 95 \%$ to $\sim 35 \%$. Dinocyst assemblages are characterized by the quasi-total disappearance of MPCs as well as significant percentages of $N$. labyrinthus $(\sim 15 \%)$. The first part of the B/A interval is characterized by increasing percentages of Brigantedinium spp. and occurrences of Impagidinium spp., while the second part of $\mathrm{B} / \mathrm{A}$ (lowest $N$. pachyderma abundances) is characterized by increasing $B$. tepikiense and cysts of $P$. dalei percentages.

\subsection{Dinocyst-based sea-surface quantifications}

\section{a. General observations on MD13-3438 results}

Our MAT-based reconstructions rely on one to five modern analogues (Fig. 4a). Overall (76 samples in total), 5 samples are scored as "good" (especially within the basal LGM interval and at the top of the B/A interval) and 45 samples are scored as "acceptable" and range between the threshold distance $\left(\mathrm{d}_{\mathrm{T}}=1.2\right)$ and $\mathrm{d}_{\mathrm{T}} / 2$ (Fig. 4a). Samples scoring as "poor" are more particularly found within HS1-b and HS1-c, intervals also characterized by fewer analogues. Fig. $4 \mathrm{a}$ shows that the $\mathrm{d}_{\mathrm{T}}$ pattern is very close to that of the H/A ratio. Consequently, uncertainties in dinocyst quantifications are likely related with heterotrophic taxa occurrences and especially with the high abundances of the Brigantedinium spp. cysts.

From the $\mathrm{n}=1968$ modern dinocyst database (de Vernal et al., 2020), 30 modern analogues are selected as the best analogues during the MAT calculations. They are mainly distributed along the eastern and western northern coasts of Canada, eastern coasts of USA, along the eastern and western coasts of Greenland and in the northern Atlantic Ocean, as well as in the Norwegian and Arctic Seas (Fig. 4b). Boxes have been delimited in Fig. $4 \mathrm{~b}$ to show the main locations of those best analogues across each time interval in Fig. 4a (color code at the right of the figure). Within the end of the LGM, best analogues are located in the western coasts of Canada and in the Norwegian Sea. Most of the modern analogues selected within HS1-a are located in the eastern coasts of USA and Canada. For HS1-b, analogues are located in the eastern and western coasts of Greenland and Svalbard. Analogues found within HS1-c are more diversified and located in the eastern coasts of USA, Canada and Greenland and in the North Sea, this latter representing the principal source of modern analogues for the upper B/A interval (Figs. 4a and $b$ ).

\section{b. Dinocyst-based sea surface parameters estimates}


382 Dinocyst-derived mean summer SSTs (Fig. 4a) vary between -0.9 and $29.6{ }^{\circ} \mathrm{C}$ (average of $38317.3^{\circ} \mathrm{C}$ ) and mean winter SSTs (Fig. 4a) range between -1.8 and $18.5^{\circ} \mathrm{C}$ (average of $7.3^{\circ} \mathrm{C}$ ).

$384 \mathrm{SST}_{\text {summer }}$ and $\mathrm{SST}_{\text {winter }}$ values show similar trends, with their highest values recorded within $385 \mathrm{HS1}-\mathrm{a}\left(\mathrm{SST}_{\text {summer }}\right.$ of $20^{\circ} \mathrm{C}$ and $\mathrm{SST}_{\text {winter }}$ of $\left.9{ }^{\circ} \mathrm{C}\right)$. These atypically elevated values, especially 386 for $\mathrm{SST}_{\text {summer}}$, exceed modern mean SSTs for the northern Bay of Biscay (modern average $387 \mathrm{SST}_{\text {summer }}$ of 17.5 and $\mathrm{SST}_{\text {winter }}$ of $11.7^{\circ} \mathrm{C}$ ). This zone is characterized by strong occurrences 388 of heterotrophic taxa (Brigantedinium spp. and MPCs), as also highlighted by the high H/A 389 ratio (Fig. 2), and modern analogues have been found along the eastern coasts of USA in 390 subtropical areas also characterized by highly productive (strong fluvial discharge) conditions 391 (modern analogue value of $\mathrm{PP}_{\mathrm{annual}}$ around $1800 \mathrm{gC} \mathrm{m}^{-2}$ ).

392 Dinocyst-derived $\mathrm{SSS}_{\text {summer }}$ and $\mathrm{SSS}_{\text {winter }}$ (Fig. 4a) show low salinities along the studied 393 section ranging between 25 and 34 psu (average of 30 psu), below mean average modern 394 values of about 35.6 psu over the northern Bay of Biscay. The lowest salinities are recorded

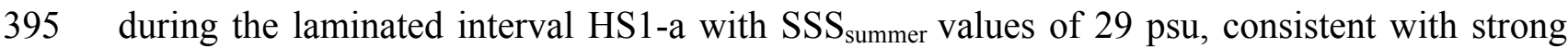
396 fluvial discharge such as observed today on the eastern coasts of USA where analogues were 397 selected (Figs. 4a, b). The highest SSS values (around $34 \mathrm{psu}$ ) are recorded in the B/A 398 interval.

399 Although quantifications are especially critical within HS1-b because of the lack of modern 400 analogues across this interval (i.e., only 3 over 11 levels provided parameter estimates based 401 on MAT), this latter appears characterized by maximal Sea Ice Cover duration ("SIC $\mathrm{D}_{\mathrm{D}}$ " of ca. 40210 months per year; Fig. 4a) and the lowest $\mathrm{SST}_{\text {summer }}$ and $\mathrm{SST}_{\text {winter }}\left(\mathrm{ca} .5{ }^{\circ} \mathrm{C}\right.$ and $-2{ }^{\circ} \mathrm{C}$, 403 respectively; Fig. 4a). Finally, reconstructed $\mathrm{PP}_{\text {annual }}$ appears the highest within HS1-a (950 $404 \mathrm{gC} \mathrm{m}$; ; Fig. 4a). 


\section{The Last Deglaciation on the northern Bay of Biscay}

406 Our compilation of MD13-3438 multiproxy signals indicative of fluvial discharge, allows us

407 to describe for the first time the consequence of those hydrographic events at sub-centennial 408 scale over the period covering the LGM to the B/A in the northern Bay of Biscay. We 409 superimpose to our new and high-resolution results some of those previously published and 410 established at lower temporal resolution (but longer time-scale) from twin core MD95-2002, 411 (Fig. 5; Fig. 6; Zaragosi et al., 2001), and highlight the additional information provided by our 412 new palynological study.

\subsection{The warm climatic conditions bracketing HS1}

415 Although the LGM and B/A are not the main targeted periods of our study, with consequently 416 few samples documenting those intervals in core MD13-3438, it is important to describe the 417 climatic context bracketing the main period of focus HS1. We thus, in the following, have 418 synthetized information consistent with earlier works (especially including those relying on 419 longer time-scale and multiproxy MD95-2002 records) and their derived climatic 420 interpretations.

\section{1 a. The end of the LGM}

422 This interval is characterized by extremely low abundances of N. pachyderma (Figs. 5 and 6) 423 and the highest percentages of O. centrocarpum (Fig. 6), considered to be a tracer of the NAC 424 (Turon, 1984; Eynaud et al., 2004, 2012; Penaud et al., 2008, 2009). It is also associated with 425 relatively high $\operatorname{SST}_{\text {winter }}\left(\sim 9^{\circ} \mathrm{C}\right.$; Fig. 6) and high SSS ( 34 psu; Fig. 6; see also Eynaud et al., 426 2012, focused on LGM salinities derived from multiproxy records). Those relatively warm 427 conditions were suggested to be induced by a significant penetration of the warm and salty 428 NAC in the Bay of Biscay (Eynaud, 1999; Zaragosi et al., 2001; Eynaud et al., 2007, 2012; 429 Penaud et al., 2009) and more generally a more vigorous NAC in the NE Atlantic Ocean 430 (Weinelt et al., 1996; Rosell-Melé and Comes, 1999; Kucera et al., 2005; de Vernal et al., 431 2000, 2002, 2005, 2006; Caulle et al., 2013; Wary et al., 2015).

432 In parallel, a slight increase of the 'Fleuve Manche' paleoriver activity is recorded (through 433 higher concentrations of reworked palynomorphs - Zaragosi et al., 2001 - and slight increase 434 of the BIT-index and C/N ratio - Ménot et al., 2006; Fig. 5), synchronously with the 19-ka 435 meltwater pulse identified in Europe by significant melting of the BIIS in Ireland (K-MWP: 
436 Kilkeel event; Clark et al., 2004; Fig. 7) and of the southern SIS (i.e., R4 event; Toucanne et 437 al., 2015; Fig. 7), while summer insolation at $65^{\circ} \mathrm{N}$ increases (Berger and Loutre, 1991; Fig. 438 7). In core MD13-3438, the end of the LGM displays small amounts of terrestrial organic matter exported to the northern Bay of Biscay and moderate marine productivity as suggested by low to moderate values of inferred PP, moderate MPCs (Fig. 5) and the lowest values of Brigantedinium spp. cyst percentages (Fig. 3).

\section{b. The onset of the $\mathrm{B} / \mathrm{A}$}

444 The onset of this relatively warm interval is characterized by a remarkable decrease in polar foraminiferal $N$. pachyderma percentages (Figs. 5 and 6) accompanied by a significant increase of $N$. labyrinthus percentages (Fig. 6) and a brief incursion of Impagidinium spp. (Fig. 3). Also, increases of dinocyst concentrations are coeval with a moderate TOC/N ratio in core MD95-2002 (Ménot et al., 2006; Fig. 5) suggesting a moderate PP increase. Since 14.6 ka BP, warmer sea-surface conditions (high $\mathrm{SST}_{\text {winter }}$ close to modern ones and high $\mathrm{W} / \mathrm{C}$ ratio; Fig. 6) are associated with a rapid SSS increase (about 34 psu; Fig. 6) highlighting a vigorous NAC with warm and salty Atlantic surface waters carried to the study area, consistent with a concomitant strong AMOC as depicted in various records from the whole North Atlantic Ocean (e.g. McManus et al., 2004; Ng et al., 2018; Fig. 7). Data acquired in the northern North Atlantic (Caulle et al., 2013; Wary et al., 2015), the western Iberian margin (Bard et al., 2000; Martrat et al., 2007; Eynaud et al., 2009; Hodell et al., 2013; Salgueiro et al., 2014; Naughton et al., 2016) and the Alboran Sea (Cacho et al., 1999; Martrat et al., 2014; Català et al., 2019) support this observation of warmer conditions at a regional scale. It appears accompanied by rapid forest development as documented in the western Mediterranean borderlands and NW Iberia at the onset of the B/A (Naughton et al., 2007, 2016; Fletcher and Sanchez-Goñi, 2008; Combourieu-Nebout et al., 2009; Camuera et al., 2019, 2021; Fig. 7) concomittant with increasing humidity, as also identified in speleothem records from southwestern Europe (Genty et al., 2006; Moreno et al., 2010; Jalut et al., 2010). An increase in seaward transfer of fluvially-derived sediments is reported directly north of the Meriadzek Terrace ca. 16-14 ka, indicating possible influence of the retreating Irish Ice Sheet (which is not connected to the 'Fleuve Manche' paleoriver) at that time (Toucanne et al., 2008). However, our data show no such evidence of deglacial meltwater fluxes at site MD133438, neither with FPT values (only a slight increase of Pediastrum spp. concentrations; Fig. 5) nor with the BIT-index (Ménot et al., 2006; Fig. 5). This lack of deglacial evidence on the 
"Meltwater Pulse 1A" (MWP-1A, Fig. 7) which occurred at around 14.6-14.3 ka BP. This led to a $20 \mathrm{~m}$ sea-level rise in less than 500 years (Weaver et al., 2003; Deschamps et al., 2012; Lambeck et al., 2014; Fig. 7) probably responsible for the displacement of the Fleuve Manche' mouth about $300 \mathrm{~km}$ eastward (Toucanne et al., 2012, 2010), thus rapidly halting any 'Fleuve Manche' imprint on the sedimentary record of our study site.

5.2. A sub-centennial subdivision of HS1 in the northern Bay of

\section{Biscay}

478 a. Early-HS1, laminated interval (HS1-a): 18.2-16.7 ka BP

\section{General observations}

480 Overall, the HS1-a interval is characterized by a huge increase in terrigenous sediment 481 supplies in the study area, evidenced through higher values of the Ti/Ca-XRF ratio (Fig. 5) 482 and higher sedimentation rates (mean values of about $200 \mathrm{~cm} / \mathrm{kyr}$ at the study site) at site 483 MD13-348, as well as through maximal values of the BIT-index (core MD95-2002; Ménot et 484 al., 2006; Fig. 5) and low CLG concentrations mainly due to dilution by terrigenous sediment 485 at site MD95-2002. This interval is also marked by a reduction of O. centrocarpum percentages from about $90 \%$ to $10 \%$ and increasing percentages of Spiniferites spp. (i.e., $S$. bentorii and S. lazus), which point to a transition from a full-oceanic (end of the LGM) to a neritic to coastal influence (cf. Penaud et al., 2020 for modern ecological requirements of dinocyst taxa in the study area) with enhanced PP (Fig. 5). This is also confirmed by high values of the Lmac/Ocen ratio (Fig. 7) and, in general, by the substantial rise of FPT values. These indications support the progradation of a large outer-shelf delta on the margin at that time and huge delivery of the 'Fleuve Manche' sediment load close to the Meriadzek Terrace

493 (Toucanne et al., 2012). Geochemical investigations suggested that the meltwater release 494 pattern is mainly related to the Baltic Ice Stream of the SIS (R5 event; Toucanne et al., 2015; 495 Fig. 7).

496 Enhanced proximal fluvio-glacial delivery from the 'Fleuve Manche' paleoriver was 497 suggested to result from the seasonal influx of meltwater from the retreating EIS and 498 responsible for the formation of the laminated facies (Zaragosi et al., 2001, 2006; Mojtahid et 499 al., 2005; Ménot et al., 2006; Eynaud et al., 2007, 2012; Toucanne et al., 2008, 2009; Penaud 500 et al., 2009; Fig. 7). Here, dinocyst-derived quantitative reconstructions further show a 501 significant drop of SSS, especially of $\operatorname{SSS}_{\text {summer }}$ (mean values about 29 psu; Fig. 6), with a 502 large seasonal SSS amplitude ( $>2$ psu; Fig. 6), suggesting that the EIS melting occurred 
mainly during the spring-summer season (Mojtahid et al., 2005; Toucanne et al., 2009, 2015;

504 Eynaud et al., 2012; see Fig. 8 for a conceptual scheme of past hydrographic changes in the 505 study area).

506 The HS1-a interval is characterized by a sustainable increase in the H/A ratio (fig. 7).

507 Interestingly, this pattern matches the AMOC trend (cf. ${ }^{231} \mathrm{~Pa} /{ }^{230} \mathrm{Th}$ values; McManus et al., 508 2004; Ng et al., 2018; Fig.7) with high values of heterotrophic cysts during the AMOC 509 slowdown in the North Atlantic Ocean and conversely. This observation highlights the 510 probable taphonomic issue linked to varying bottom water ventilation (Zonneveld et al., 511 2008). In our study, heterotrophics (Fig. 5) may be related to either increasing PP and/or 512 better preservation of peridinioid cysts under low bottom-water oxygenation. Remarkably, 513 benthic foraminiferal taxa, from the northern Bay of Biscay, indicated both a general 514 eutrophication and a severe bottom water dysoxia in the sea floor (Mojtahid et al., 2017). 515 Overall cold and dry conditions are observed in the southern and western Iberian Peninsula, 516 with a strong reduction of the Mediterranean and temperate forests (Fletcher and Sanchez 517 Goñi, 2008; Naughton et al., 2016; Camuera et al., 2021; Fig.7) and a notable increase of 518 xerophytic taxa (i.e., steppic taxa) (Camuera et al., 2021; Fig.7).

\section{Sub-centennial variability of fluvio-glacial discharge on northern Bay of Biscay}

521 Our unprecedented high-resolution multiproxy study of the laminated facies shows a new sub522 centennial-scale structure, following a multi-step scenario encompassing 5 intervals (Figs. 5 523 to 7; cf. subsection 4.1). Enhanced fluvial inputs were recorded within HS1-a2 corresponding 524 to maximal terrestrial advection and HS1-a4 consisting to the strongest stratification level of 525 the surface water column and the strongest westward shift of the freshwater front toward the 526 ocean (Fig. 5). Interestingly, these intervals are characterized by lower and fluctuating $N$.

527 pachyderma percentages and increased values of SST and seasonality reconstructed from 528 dinocysts at site MD13-3438, testifying warm sea-surface conditions (Fig. 6). Decreased 529 fluvial discharge marked the HS1-a1, HS1-a3 and HS1-a5 intervals, this latter appears 530 characterized by the establishment of cold sea surface conditions in the northern Bay of 531 Biscay within the latter.

532 The oscillating pattern of 'Fleuve Manche' paleoriver runoff illustrated here by the different 533 phases identified in HS1-a finds a striking echo in the environmental fluctuations from arid to 534 more humid conditions in the Iberian Peninsula between 18.4 and 16.4 ka BP (Camuera et al., 535 2021: Fig. 7), with phases of higher runoff matching those of increased humidity in southern 
536 Europe. Furthermore, these observations are regionally supported by SST records from the Alboran Sea (Cacho et al., 1999, 2006; Martrat et al., 2014; Fig.7).

The role of multidecadal changes in seasonality on fluvio-glacial fluxes to the northern

\section{Bay of Biscay}

541 The first conceptual model proposed by Mojtahid et al. (2005) suggested: (i) enhanced

542 melting of EIS and surrounding glaciers, responsible for enhanced clay and CLG fluxes to the

543 Bay of Biscay via the 'Fleuve Manche' paleoriver during spring and especially summer seasons, and (ii) freezing SST and sea-ice cover establishment inhibiting EIS melting during winter seasons. While first studies attributed CLG-rich units to the seasonal calving of EIS icebergs onto the northern Bay of Biscay (Mojtahid et al., 2005; Zaragosi et al., 2006; Eynaud et al., 2007), Toucanne et al (2009) later proposed that the episodic rainout of these particular CLG originates instead from the 'Fleuve Manche' paleoriver discharge of anchor-ice (i.e., ice attached to the riverbed) and of sediment-rich frazil-ice (Reimnitz and Kempama, 1987;

550 Kempama et al., 2001).

551 Echoing the seasonal dynamic of the 'Fleuve Manche' paleoriver, our data interestingly suggest warmer sea-surface conditions within HS1-a (mean SST values about $\sim 9^{\circ} \mathrm{C}$ and high values of the W/C ratio; Figs. 6) associated with a significant temperature seasonality increase

$554\left(>12^{\circ} \mathrm{C}\right.$; Fig. 6$)$, especially within periods of maximal fluvial discharge, namely HS1-a2 and 555 HS1-a4. To further investigate this, we specifically created a 'summer versus winter index' as 556 the ratio between two major dinocyst taxa occurring regionally and illustrating two opposite 557 environmental dynamics: the estuarine taxon L. machaerophorum and the polar taxon $I$. minutum (Lmac/Imin ratio; Fig.7). We consider L. machaerophorum, whose highest abundances at present are encountered in areas under strong fluvial influence, as characteristics of the 'Fleuve Manche' paleoriver discharge induced by European ice sheet retreat and melting during the deglaciation, i.e., which occurred preferentially during summer seasons according to earlier sedimentological studies cited above. In contrast, occurrences of the polar species I. minutum are associated with cold sea-surface conditions and expansion of temporary sea-ice cover (1-3 months/year, Fig. 6) over the studied interval in the northern Bay of Biscay (as it is at present at high latitudes), then mostly expressing a winter signal (Fig. 8).

567 The Lmac/Imin ratio (Fig. 7) matches the seasonality signal (Fig. 6). It shows high values within most of the HS1-a interval and particularly during maximal runoff periods HS1-a2 and HS1-a4. On the contrary, intervals characterized by lower fluvio-glacial inputs (HS1-a1, HS1- 
a3 and HS1-a5) depict low Lmac/Imin values, highlighting the limited influence of summer seasons and the prevalence of cold winters (Fig. 8). We thus argue that multidecadal changes of the seasonality pattern played a substantial role on the EIS and 'Fleuve Manche' paleoriver sub-centennial dynamics during the last deglaciation, with release of river ice and meltwater via the 'Fleuve Manche' paleoriver favoured during episodes with prevailing summer mode, and reversely formation of anchor- and frazil-ice in the 'Fleuve Manche' paleoriver favoured during episodes of winter prevailing mode (see Fig. 8 for a conceptual scheme of past hydrographic changes in the study area). Such an enhanced warm summer-prevailing mechanism could then explain the EIS melting, as far as in the northern European lowlands, in an 'apparent' long cold climate stadial (Fig. 8). HS1 is generally seen as a very cold and dry interval in the North Atlantic Ocean and across Europe (Bard et al., 2000), marked by overall light NGRIP $\delta^{18} \mathrm{O}$ values, especially during HE1 (Fig. 7). The strong changes in SST seasonality observed in the northeastern Atlantic

583 Ocean, and weakly expressed in high latitudes, may then support the hypothesis that

584 Greenland temperatures mainly represent winter temperatures (Denton et al., 2005, 2010; 585 Buizert et al., 2014, 2018). However, it is worth noting the occurrence of a plateau of slightly 586 lighter NGRIP $\delta^{18} \mathrm{O}$ values over the HS1-a interval (Fig. 7) arguing for slightly warmer atmospheric conditions.

\section{b. Late-HS1, namely HE1 layer (HS1-b and HS1-c): 16.7-14.6 ka BP}

590 In our study, at $16.7 \mathrm{ka} \mathrm{BP}$, the onset of HE1 phase is characterized by the disappearance of

591 laminae deposits as well as a drastic drop of sedimentation rates (from 156 to $41 \mathrm{~cm} / \mathrm{kyr}$; Fig.

592 5) and in the BIT-index (Ménot et al., 2006; Fig. 5). Those changes are associated with a substantial decline of FPT values including the Lmac/Ocen ratio. All these observations point

594 to a considerable decrease of the 'Fleuve Manche' paleoriver runoff. Also, high values of $595 \mathrm{C}_{37: 4}$ alkenones (i.e., a biomarker derived from haptophyte algae, and used as a proxy for low 596 salinity water associated with icebergs; Ménot et al., 2006) are synchronous with high CLG 597 concentrations (Fig. 6). The local hydrology is thus strongly impacted by both Laurentide598 and European-derived icebergs at that time (Grousset et al., 2000). Increasing percentages of 599 the polar species I. minutum (Fig. 6), recognized as a good tracer of cold surface waters 600 seasonally to quasi-permanently covered with sea-ice (Zonneveld et al., 2013; Radi et al., 601 2013), are synchronous with low reconstructed $\mathrm{SST}_{\text {winter }}$ (Fig. 6) indicating cold sea-surface 602 conditions (Fig. 6). 
603 Dinocyst assemblages enabled us to determine two sub-zones, HS1-b and HS1-c, with a 120 years study resolution on the entire HE1 interval:

605 HS1-b (16.7-15.6 ka BP; 85 years study resolution) is characterized by the drastic decrease 606 of fluvial inputs (low FPT values, Fig. 5; decreasing Lmac/Ocen ratio, Fig. 7). Maximal $I$. 607 minutum (Fig. 6) and S. septentrionalis (Fig. 3) occurrences are recorded at 16.4 ka BP, 608 depicting the coldest conditions (Figs. 6 and 7). Low O. centrocarpum percentages 609 additionally suggest a still weakened NAC, consistently with ${ }^{231} \mathrm{~Pa} /{ }^{230} \mathrm{Th}$ record which 610 suggests that a weakened AMOC state persisted for over a millennium $(\sim 16.5-15 \mathrm{ka} \mathrm{BP})$ in 611 the North Atlantic Ocean (Ng et al., 2018; Fig. 7). These cold surface conditions recorded on 612 the northern Bay of Biscay may have been responsible for a weaker EIS melting and are 613 consistent with records from the IRD belt indicating a widespread cooling associated with a 614 major calving episode of the LIS (Stanford et al., 2011; Hodell et al., 2017). This interval is 615 indeed marked by a notable peak of magnetic susceptibility (Figs. 5 and 6) and significant 616 CLG concentrations (core MD95-2002; Figs. 5 and 6) accompanied by minimal values of the 617 Ti/Ca-XRF ratio at 16 ka BP (Fig. 5) indicative of carbonate-rich CLG (Auffret et al., 1996; 618 Toucanne, 2009;). This may correspond to the 'cemented marls' of Hemming (2004) 619 interpreted as the LIS (i.e., Hudson Strait) iceberg delivery to the North Atlantic Ocean 620 (Toucanne et al., 2015).

621 Extremely cold conditions at our study site (Figs. 6, 7 and 8) are synchronous with extremely 622 cold boreal temperatures (lightest NGRIP $\delta^{18} \mathrm{O}$ values of the entire HE1 phase; Fig. 7) and 623 with the coldest and most arid environments documented in marine palynological sequences 624 from the Alboran Sea (Combourieu-Nebout et al., 2002, Fletcher and Sanchez Goñi, 2008; 625 Fig7) and off the Iberian Peninsula (Turon et al., 2003; Naughton et al., 2007, 2009, 2016). 626 The dryness over the Mediterranean borderlands increased (Morellón et al., 2009; Camuera et 627 al., 2019; Fig. 7) in relation with the southward migration of the polar front (Eynaud et al., 628 2009).

629 HS1-c (15.6-14.6 ka BP; 170 years study resolution) is characterized by higher percentages 630 of $B$. tepikiense and $P$. dalei cysts, currently observed in surface sediments from the subpolar 631 North Atlantic basin (Harland, 1983; de Vernal et al., 1992; Dale, 1996; Rochon et al., 1999), 632 and also clearly accompanied by both decreasing I. minutum percentages and CLG 633 concentrations (Figs. 5 and 6) as well as increasing O. centrocarpum percentages (Fig. 3). 634 This suggests warm sea-surface conditions (Fig. 6) with increased thermal seasonal 635 amplitudes (Figs. 6, 7 and 8). The retreat of winter sea-ice marks the end of the HS1 interval 636 in the northeastern Atlantic Ocean. Increasingly warm conditions on the northern Bay of 
637 Biscay are consistent with an intensified NAC and increasing SSTs as detected at regional 638 scale (e.g., Caulle et al., 2013; Wary et al., 2015; Naughton et al., 2016; Hodell et al., 2013; 639 Cacho et al., 1999; Martrat et al., 2014; Català et al., 2019). Also, warmer and more humid 640 conditions are observed in the southern and western Iberian Peninsula (Fletcher and Sanchez 641 Goñi, 2008; Naughton et al., 2009, 2016; Camuera et al., 2021; Fig.7) that may be attributed 642 to the northward displacement of the polar front (Cayre et al., 1999; Naughton et al., 2009, 643 2016). 


\section{Conclusion}

645 The high-resolution palynological investigation of the last deglaciation in core MD13-3438

646 (northern Bay of Biscay) highlights significant climatic and paleoenvironnmental changes 647 related to both the proximal European Ice Sheets (EIS) and the 'Fleuve Manche' paleoriver 648 dynamics. Dinocyst-based quantitative reconstructions provide an evaluation of past 649 hydrographical changes. Seven short-scale sub-phases within the HS1 interval were identified 650 for the first time on the northern Bay of Biscay:

651 HS1-a (i.e., laminated interval; $18.2-16.7 \mathrm{ka} \mathrm{BP}$ ) is generally characterized by marked multidecadal changes in the seasonality range, i.e., warm summers resulting in enhanced EIS melting and 'Fleuve Manche' paleoriver runoff, causing the largest drop of SSS and cold winters resulting in freezing conditions and lower 'Fleuve Manche' paleoriver activity. Fluvial-derived palynological tracers indicate that this interval is subdivided into five subphases. Two maximal meltwater episodes (HS1-a2, 17.8-17.6 ka BP and HS1-a4, 17.4-17 ka BP) are detected, with substantial erosional processes in the 'Fleuve Manche' basin and strong stratification of the water column. Both events correspond to strong seasonality phases dominated by summer-prevailing modes. Fluvio-glacial discharge of the 'Fleuve Manche' paleoriver, although significant, is comparatively moderate during HS1-a1 (18.2-17.8 ka BP), HS1-a3 (17.6-17.4 ka BP) and HS1-a5 (17-16.7 ka BP), and possibly result from a decrease of the seasonality that could have limited the EIS melting at that time. Indeed, our new data suggest winter-prevailing modes at that time.

664 HS1-b (i.e., first phase of HE1; 16.7-15.6 ka BP) includes the Laurentide-sourced IRDs recorded at $\sim 16 \mathrm{ka}$ BP. This interval is characterized by a substantial decrease of proximal fluvial inputs and cold winters. Cooling sea-surface conditions are recorded with seasonal winter sea-ice cover occurrences and the lowest reconstructed SSTs. HS1-c (i.e., second phase of HE1; 15.6-14.6 ka BP) is characterized by warmer sea-surface conditions, suggesting the advection of Atlantic surface waters conveyed by the NAC and leading to the transition to the warm $\mathrm{B} / \mathrm{A}$.

671 Our reconstructed sub-centennial variability suggests the crucial role of multidecadal seasonal changes, especially within the early HS 1 interval, for fluvio-glacial dynamics and the melting of the EIS. Furthermore, our records are in agreement with marine and terrestrial sequences from the western Mediterranean basin suggesting common regional forcings acting on the multi-scale climate variability across the last deglaciation. 


\section{7. Acknowledgments}

679 This work was supported by the French projects: ANR IDEGLACE, INSU RISCC, INSU 680 ICE-BIO-RAM and by the European Research Council ERC grant ACCLIMATE/n 339108. 681 This work results from regional, national and international collaborations, between LGO 682 laboratory (Brest University,), Ifremer (GM), EPOC laboratory (Bordeaux University,), LSCE 683 and the Universitat Autònoma of Barcelona. We received funding from the CG29 (Conseil 684 Général du Finistère, 29) and financial support from LGO and EPOC laboratories. This work was also supported by ISblue project, Interdisciplinary graduate school for the blue planet (ANR-17-EURE-0015) and co-funded by a grant from the French government under the program "Investissements d'Avenir". We thank Mikael Rovere and Patrice Woerther for their assistance onboard the R/V Marion Dufresne, Muriel Georget (EPOC) and Pierre-Olivier Coste (LGO) for their help and laboratory assistance. Mélanie Wary's contribution was also supported through funding from the Spanish Ministry of Science, Innovation and Universities, through the "María de Maeztu" program for Units of Excellence (MDM-2015-0552).

\section{Table caption}

Table 1: Datasets acquired on both cores MD95-2002 and MD13-3438 with their corresponding references.

Table 2: List of tie points defined by aligning the Ti/Ca-XRF signal of the well-dated core MD95-2002 with that of the studied core MD13-3438.

Table 3: List of identified autotrophic and heterotrophic dinocyst taxa according to their ecological preferences: cold surface-waters (in blue; C) and warm surface-waters (in orange; $\mathrm{W})$. The Warm/Cold qualitative temperature index is based on these $\mathrm{W}$ and $\mathrm{C}$ species.

\section{Figure captions}

707 Figure 1: Paleogeographic reconstruction of western Europe during the LGM ( $20 \mathrm{ka} \mathrm{BP})$ modified from Toucanne et al. (2015) and records of the past fluvial activity of the Fleuve Manche' paleoriver. a) The yellow star corresponds to the location of the study core MD13- 
3438 and of the core MD95-2002. Black lines represent the extension of the Northern

711 Hemisphere ice caps: (1) the European Ice Sheet (EIS) including the Scandinavian (SIS) and

712 British-Irish Ice Sheets (BIIS) (Boulton et al., 2001; Clark et al., 2012b; Ehlers et al., 2011), 713 with their main fluvio-glacial paths (black arrows), as well as the Alpine Ice Sheet; and (2)

714 the Laurentide Ice Sheet (LIS) with main fluvio-glacial path (white arrow). The bold white 715 arrow identifies the drainage of the 'Fleuve Manche' paleoriver. The North Atlantic surface 716 circulation (red arrows for the warmer North Atlantic Current (NAC) and its branches) is also 717 shown with the return flow pathway of the deep waters (blue arrows). White shading indicates 718 the extent of the EIS and LIS. The trajectory of the icebergs from the LIS are represented 719 with light blue arrows and white arrows indicate the main supply sources of freshwater to the 720 North Atlantic. b) Interval from 40 to $5 \mathrm{ka} \mathrm{BP}$ : July insolation at $65^{\circ} \mathrm{N}$ (Berger and Loutre, 721 1991), Greenland $\delta^{18} \mathrm{O}$ record (GICC05; Svensson et al., 2008, in black), Ti/Ca- XRF data 722 and N. pachyderma abundances of core MD13-3438 (blue) compared with the MD95-2002 723 dataset (in red) including: N. pachyderma abundances (Zaragosi et al., 2001), coarse lithic 724 grain concentrations (CLG; $10^{3}$ grains/g dry sed.; Zaragosi et al., 2001), magnetic susceptibility of bulk sediment (U em ; Grousset et al., 2000), fluvial input proxies (number of laminae per cm, concentrations of freshwater micro-algae Pediastrum spp.; Zaragosi et al., 2001) and the branched and isoprenoid tetraether (BIT) index (Ménot et al., 2006). Light grey band represents the LGM (23-19 ka BP) while blue band allows visualizing HS1 in both cores MD95-2002 and MD13-3438 (18.4-14 ka BP). Dark grey band represents the conventional HE1 layer occurring at $\sim 16 \mathrm{ka} B P$.

Figure 2: Palynological data against depth $(\mathrm{cm})$ with taxonomical indices (species richness, black; Margalef index, grey), percentages of the most abundant taxa Brigantedinium spp., ratio between Heterotrophic and Autotrophic (H/A) dinocysts (grey), percentages of $L$. machaerophorum, ratio between L. machaerophorum and O. centrocarpum (grey), concentrations of reworked dinocysts (blue) and of total freshwater microalgae (dark grey line: including Botryococcus spp. (purple), Concentricystes spp. (pink) and Pediastrum spp. (green)). The reworked (pre-Quaternary) vs. modern (in situ) cyst ratio ( $\mathrm{Rd} / \mathrm{Md}$ ) is highlighted in grey. Horizontal lines delineate the nine palynozones / climatic subdivisions discussed in the manuscript. LGM: Last Glacial Maximum; HS1-a1 to HS1-a5: Laminated interval; HS1-b and HS1-c: Heinrich Event 1; B/A: Bølling/Allerød.

743 Figure 3: Diagram of dinocyst assemblages (i.e., major taxa with values higher than $2 \%$ at 
744 least once in palynological assemblages) versus depth (cm) for core MD13-3438, compared with the relative abundances of the planktonic foraminiferal species $N$. pachyderma and with total dinocyst concentrations (black line) including autotrophic (black dotted line) and heterotrophic (grey dotted line) taxa $\left(\right.$ cysts $\left./ \mathrm{cm}^{3}\right)$. Red and black stars indicate AMS $-{ }^{14} \mathrm{C}$ dates obtained from cores MD95-2002 and MD03-2690 (Eynaud et al., 2012; Mojtahid et al., 2005; Toucanne et al., 2008; 2015; Zaragosi et al., 2006; Zaragosi et al., 2001) respectively, and grey star refers to the NGRIP tie point used for the MD95-2002 age model. These ages are here projected as equivalent depths for core MD13-3438 using the twins Ti/Ca-XRF signals of both MD95-2002 and MD13-3438 cores (Fig. 1b). Palynozones/climatic subdivisions were based on dinocyst clustering established by Psimpoll program. Horizontal lines delineate the nine palynozones discussed in the manuscript (same as in Fig. 2). High percentages of dinocyst taxa are shown by orange vertical arrows for long-lasted periods and by dotted orange vertical arrows for short periods.

Figure 4: a) Dinocyst-based environmental parameters reconstructed for core MD13-3438 with the Modern Analog Technique (MAT) using the $n=1968$ modern dinocyst database (de Vernal et al., 2020) versus depth: SST and SSS for the summer (red dotted line) and winter (blue dotted line), PP annual (black dotted line), and Sea Ice cover Duration (months/year; grey dotted line). Number of analogues found for each assemblage (minimum of 0 and maximum of 5 allowed with the MAT; dark red). Distances between fossil MD13-3438 assemblages and their "closest" modern analogue (i.e., Dmin). Threshold distance value $\left(\mathrm{d}_{\mathrm{T}}=1.2\right.$; red line) for quantification robustness: good analogues if Dmin is between 0 (perfect analogue) and $\mathrm{d}_{\mathrm{T}} / 2$ (orange line); acceptable analogues if Dmin is between 0.6 and $\mathrm{d}_{\mathrm{T}}=1.2$, and poor analogues (i.e. caution with quantifications) if Dmin $>d_{T}$ (de Vernal et al., 2005). Horizontal lines delineate the nine palynozones / climatic subdivisions discussed in the manuscript (same as in Fig. 2 and 3). b) Map showing the geographical distribution of the closest analogues (i.e., corresponding to Dmin) selected by the MAT for the studied section of core MD13-3438 (environmental dataset also from de Vernal et al., 2020). Analogues have been grouped according to geographical areas (color code for boxes; also repeated in Fig. 4a for source area of closest analogues in each palynozone).

Figure 5: Deglacial records of the 'Fleuve Manche' paleoriver activity on the northern Bay of Biscay between 18.4 and 14 ka BP. For core MD13-3438 (in blue): N. pachyderma percentages, sedimentation rates $(\mathrm{cm} / \mathrm{kyr})$, Ti/Ca-XRF ratio, freshwater microalgae 
778 Pediastrum spp. concentrations $\left(10^{3}\right.$ algae $\left./ \mathrm{cm}^{3}\right)$, reworked dinocyst concentrations $\left(10^{3}\right.$ 779 cysts $\left./ \mathrm{cm}^{3}\right)$, L. machaerophorum percentages and concentrations $\left(10^{3}\right.$ cysts $\left./ \mathrm{cm}^{3}\right)$, 780 reconstructed $\mathrm{PP}$ annual $\left(10^{3} \mathrm{~g} \mathrm{C} \mathrm{m}^{-2}\right)$ and peridinioid cyst concentrations $\left(10^{3} \mathrm{cysts} / \mathrm{cm}^{3}\right)$. For core MD95-2002 (in red): N. pachyderma percentages, coarse lithic grain concentrations CLG

782 ( $10^{3}$ grain/g dry sed.), number of laminae (laminae/cm), Reworked versus Modern dinocyst 783 ratio ( $\mathrm{Rd} / \mathrm{Md}$, shaded red), L. machaerophorum percentages (shaded red) (Zaragosi et al., 784 2001), magnetic susceptibility of bulk sediment (U em; Grousset et al., 2000), Ti/Ca-XRF 785 ratio (Toucanne et al., 2015), branched and isoprenoid tetraether (BIT index; Ménot et al., 786 2006) and Carbon/Nitrogen ratio (C/N; Ménot et al., 2006). Yellow bands highlight periods of 787 reduced runoff (HS1-a1, HS1-a3 and HS1-a5) and orange bands correspond to the periods of 788 maximal fluvio-glacial discharge. Blue and pink bands highlight the HE1 phase (HS1-b, 789 including the conventional HE1 layer at $16 \mathrm{ka} \mathrm{BP}$, and HS1-c, respectively). Horizontal lines 790 delineate the nine palynozones / climatic subdivisions discussed in the manuscript (same as in 791 Fig. 2, 3 and 4).

Figure 6: Reconstructed hydrological parameters derived from dinocyst assemblages of the core MD13-3438 (in blue, this study) compared with data from MD95-2002 (in red; Zaragosi et al., 2001). N. pachyderma percentages, coarse lithic grain concentrations CLG, magnetic susceptibility of bulk sediment (U em ; Grousset et al., 2000), and number of laminae are compiled with relative abundances of the main dinocyst species, percentages of C37:4 among C37 alkenones (red, Ménot et al., 2006), Warm/Cold dinocyst ratio (W/C, This study), dinocyst-derived sea-surface parameters of MD13-3438 (Sea Surface Temperatures: SST $_{\text {winter }}$ in blue, $\mathrm{SST}_{\text {summer }}$ in orange; Sea Surface Salinity: $\mathrm{SSS}_{\text {summer-winter}}$; Seasonality (SST summerSST winter). Yellow bands highlight periods of reduced runoff (HS1-a1, HS1-a3 and HS1-a5) and orange bands correspond to the periods of maximal fluvio-glacial discharge. Blue and pink bands highlight the HE1 phase (HS1-b and HS1-c, respectively). Horizontal lines delineate the nine palynozones / climatic subdivisions discussed in the manuscript (same as in 806

807 Figure 7: Synthesis of main information regarding regional paleoclimatic reconstructions for 808 the last deglaciation and our climate subdivisions especially within HS1.

809 Composite Relative Sea Level (RSL) curve (Lambeck et al., 2014) with identified K-MWP at $81019 \mathrm{ka} \mathrm{BP}$ and MWP-1A at $\sim 14.6 \mathrm{ka} \mathrm{BP}$, July Insolation curve at $65^{\circ} \mathrm{N}$ (Berger and Loutre, 811 1991), $\delta^{18} \mathrm{O}$ NGRIP record (GICCO05; Svensson et al., 2008), ${ }^{231} \mathrm{~Pa} /{ }^{230} \mathrm{Th}$ signal (Ng et al., 
812 2018), N. pachyderma percentages (blue, this study; red for the core MD95-2002 (Zaragosi et 813 al., 2001)), H/A ratio (blue, this study; has been also translated and reversed for comparison),

814 Runoff events (R) 4 and 5 (core MD95-2002, Toucanne et al., 2015), L. machaerophorum 815 versus O. centrocarpum (Lmac/Ocen ratio, This study), L. machaerophorum versus I. 816 minutum (Lmac/Imin ratio, This study), dinocyst-derived sea-surface seasonality 817 (SSTsummer-SSTwinter) and three-point moving average of Xerophyte and Mediterranean 818 forest percentages from southern Spain (Camuera et al., 2021) as well as temperate forest 819 percentages from the Alboran Sea (Fletcher and Sanchez Goñi, 2008). The proposed 820 comparison respects dating uncertainties and strong reservoir age impacts at that time may be 821 responsible for generating temporal offsets between records.

822 Dashed grey lines correspond to original values, whereas continuous lines correspond to 823 smoothed data. Yellow bands highlight periods of reduced runoff (HS1-a1, HS1-a3 and HS1-

824 a5) and orange bands correspond to periods of maximal fluvio-glacial discharge. Blue and 825 pink bands highlight the HE1 phase (HS1-b, including the conventional HE1 layer at 16 ka, 826 and HS1-c, respectively).

828 Figure 8: Conceptual model illustrating hydrological conditions and processes involved for 829 fluvio-glacial dynamics across the HS1 interval in the northern Bay of Biscay.

\section{Appendix caption}

Appendix: Exhaustive table of palynological results (percentages, concentrations and reconstructed parameters)

\section{References}

837 Andersen, K. K., Svensson, A., Johnsen, S. J., Rasmussen, S. O., Bigler, M., Röthlisberger, R., et al., 2006. The Greenland ice core chronology 2005, 15-42 kyr. Part 1: constructing the time scale. Quat. Sci. Rev. 25, 3246-3257.

Auffret, G.A., Boelaert, A., Vergnaud-Grazzini, C., Muller, C., Kerbrat, R., 1996. Identification of Heinrich layers in core KS 01 North-Eastern Atlantic $\left(46^{\circ} \mathrm{N}, 17^{\circ} \mathrm{W}\right)$, implications for their origin. Mar. Geol. 131, 5-20.

Auffret, G., Zaragosi, S., Voisset, M., Droz, L., Loubrieu, B., Pelleau, P., Savoye, B., Bourillet, J.-F., Baltzer, A., Bourquin, S., Dennielou, B., Coutelle, A., Weber, N., 
Floch, G., 2000. First observations on the morphology and recent sedimentary processes of the Celtic Deep Sea Fan [Premieres observations sur la morphologie et les processus sedimentaires recents de l'Eventail celtique]. Oceanologica Acta 23, $109-116$.

Auffret, G., Zaragosi, S., Dennielou, B., Cortijo, E., Van Rooij, D., Grousset, F., Pujol, C., Eynaud, F., Siegert, M., 2002. Terrigenous fluxes at the Celtic margin during the last glacial cycle. Mar. Geol. 188, 79-108.

Bard, E., Rostek, F., Turon, J.L., Gendreau, S., 2000. Hydrological impact of Heinrich events in the subtropical Northeast Atlantic. Science 289, 1321-1324.

Barker, S., Diz, P., Vautravers, M. J., Pike, J., Knorr, G., Hall, I. R., Broecker, W. S., 2009. Interhemispheric Atlantic seesaw response during the last deglaciation. Nature 457, 1097-1102.

Bassinot, F., Labeyrie, L., 1996. IMAGES I, MD101: A coring cruise of the R/V Marion Dufresne in the North Atlantic Ocean and Norwegian Sea. Les rapports de campagnes à la mer. Institut Paul-Emile Victor (IPEV).

Berger, A., Loutre, M.F., 1991. Insolation values for the climate of the last 10 million years. Quat. Sci. Rev. 10, 297-317.

Berx, B., Hansen, B., Østerhus, S., Larsen, K. M., Sherwin, T., Jochumsen, K., 2013. Combining in-situ measurements and altimetry to estimate volume, heat and salt transport variability through the Faroe Shetland Channel. Ocean Science Discussions, 10.

Blaauw, M., 2010. Methods and code for 'classical' age-modelling of radiocarbon sequences. Quat. Geochronol. 5, 512-518.

Bond, G.W., Heinrich, H., Broecker, W., Labeyrie, L., McManus, J., Andrews, J., Huon, S., Jantschik, R., Clasen, S., Simet, C., Tedesco, K., Klas, M., Bonani, G., Ivy, S., 1992. Evidence for massive discharges of icebergs into the North Atlantic Ocean during the last glacial period. Nature 360, 245-249.

Bond, G., Broecker, W., Johnsen, S., McManus, J., Labeyrie, L., Jouzel, J., Bonani, G., 1993. Correlations between climate records from North Atlantic sediments and Greenland ice. Nature 365, 143-147.

Bond, G., Showers, W., Cheseby, M., Lotti, R., Almasi, P., deMenocal, P., Priore, P., Cullen, H., Hajdas, I., Bonani, G., 1997. A pervasive millennial-scale cycle in North Atlantic Holocene and glacial climates. Science 278, 1257-1266. 
Bond, G., Showers,W., Elliot, M., Evans, M., Lotti, R., Hajdas, I., Bonani, G., Johnson, S., 1999. The north Atlantic's 1-2 kyr climate rhythm: relation to Heinrich events, Dansgaard/Oeschger cycles and the little ice age. In: Clark, P.U., Webb, R.S., Keigwin, L.D. (Eds.), Mechanisms of Global Climate Change at Millennial Time Scales. American Geophysical Union, Washington, D.C, 35-58.

Boulton, G.S., Dongelmans, P., Punkari, M., Broadgate, M., 2001. Paleoglaciology of an ice sheet through a glacial cycle: the European ice sheet through the Weichselian. Quat. Sci. Rev. 20, 591-625.

Bourillet, J.-F., Reynaud, J.-Y., Baltzer, A., Zaragosi, S., 2003. The 'Fleuve Manche': the submarine sedimentary features from the outer shelf to the deep-sea fans. J. Quat. Sci. $18,261-282$.

Broecker, W., Bond, G., Klas, M., Clark, E., McManus, J., 1992. Origin of the northern Atlantic's Heinrich events. Clim. Dyn. 6, 265-273.

Broecker, W.S., 1994. Massive iceberg discharges as triggers for global climate change. Nature 372, 421-424.

Buizert, C., Gkinis, V., Severinghaus, J. P., He, F., Lecavalier, B. S., Kindler, P., et al., 2014. Greenland temperature response to climate forcing during the last deglaciation. Science 345, 1177-1180.

Buizert, C., Keisling, B. A., Box, J. E., He, F., Carlson, A. E., Sinclair, G., De Conto, R. M., 2018. Greenland-wide seasonal temperatures during the last deglaciation. Geophys. Res. Lett. 45, 1905-1914.

Cacho, I., Grimalt, J. O., Pelejero, C., Canals, M., Sierro, F. J., Flores, J. A., Shackleton, N., 1999. Dansgaard-Oeschger and Heinrich event imprints in Alboran Sea paleotemperatures. Paleoceanography 14, 698-705.

Cacho, I., Shackleton, N., Elderfield, H., Sierro, F. J., Grimalt, J. O., 2006. Glacial rapid variability in deep-water temperature and $\delta^{18} \mathrm{O}$ from the Western Mediterranean Sea. Quat. Sci. Rev. 25, 3294-3311.

Camuera, J., Jimenez-Moreno, G., Ramos-Román, M.J., García-Alix, A., Toney, J.L., Anderson, R.S., Jimenez-Espejo, F., Bright, J., Webster, C., Yanes, Y., 2019. Vegetation and climate changes during the last two glacial-interglacial cycles in the western Mediterranean: a new long pollen record from Padul (southern Iberian Peninsula). Quat. Sci. Rev. 205, 86-105.

Camuera, J., Jiménez-Moreno, G., Ramos-Román, M. J., García-Alix, A., Jiménez-Espejo, F. J., Toney, J. L., Anderson, R. S., 2021. Chronological control and centennial-scale 
climatic subdivisions of the Last Glacial Termination in the western Mediterranean region. Quat. Sci. Rev. 255, 106814.

Català, A., Cacho Lascorz, I., Frigola Ferrer, J. I., Pena, L. D., Lirer, F., 2019. Holocene hydrography evolution in the Alboran Sea: A multi-record and multiproxy comparison. Clim. Past. 15, 927-942.

Caulle, C., Penaud, A., Eynaud, F., Zaragosi, S., Roche, D. M., Michel, E., Boulay, S., Richter, T., 2013. Sea-surface hydrographical conditions off South Faeroes and within the North-Eastern North Atlantic through MIS 2: The response of dinocysts. J. Quat. Sci. 28, 217-228.

Cayre, O., Lancelot, Y., Vincent, E., 1999. Paleoceanographic reconstructions from planktonic foraminifera off the Iberian Margin: temperature, salinity, and Heinrich events. Paleoceanography 14, 384-396.

Clark, P.U., McCabe, A.M., Mix, A.C., et al. 2004. Rapid rise of sea level 19,000 years ago and its global implications. Science 304, 1141-1144.

Clark, P. U., Shakun, J. D., Baker, P. A., et al., 2012a. Global climate evolution during the last deglaciation. Proc. Natl. Acad. Sci. 109, 1134-1142.

Clark, C.D., Hughes, A.L.C., Greenwood, S.L., Jordan, C., Sejrup, H.S., 2012b. Pattern and timing of retreat of the last British-Irish Ice Sheet. Quat. Sci. Rev. 44, 112-146.

Combourieu Nebout, N., Londeix, L., Baudin, F., Turon, J. L., Von Grafenstein, R., 1999. Quaternary marine and continental paleoenvironments in the western Mediterranean (Site 976, Alboran Sea): palynological evidence. In Proceedings of the Ocean Drilling Program. Scientific Results 161, 457-468.

Combourieu-Nebout N., Turon, J. L., Zahn, R., Capotondi, L., Londeix, L., Pahnke, K., 2002. Enhanced aridity and atmospheric high-pressure stability over the western Mediterranean during the North Atlantic cold events of the past $50 \mathrm{ky}$. Geology 30, 863-866.

Combourieu-Nebout, N., Peyron, O., Dormoy, I., Desprat, S., Beaudouin, C., Kotthoff, U., Marret, F., 2009. Rapid climatic variability in the west Mediterranean during the last 25000 years from high resolution pollen data. Clim. Past. 5, 503-521.

Conkright, M. E., Locarnini, R. A., Garcia, H. E., O'Brien, T. D., Boyer, T. P., Stephens, C., Antonov, J. I., 2002. World Ocean Atlas 2001: Objective analyses, data statistics, and figures: CD-ROM documentation. 
944 Cossa, D., Cotté-Krief, M. H., Mason, R. P., Bretaudeau-Sanjuan, J. J. M. C., 2004. Total

945

946

947

948

949

950

951

952

953

954

955

956

957

958

959

960

961

962

963

964

965

966

967

968

969

970

971

972

973

974

975

976 mercury in the water column near the shelf edge of the European continental margin. Marine Chemistry 90, 21-29.

Daniault, N., Mercier, H., Lherminier, P., Sarafanov, A., Falina, A., Zunino, P., et al., 2016. The northern North Atlantic Ocean mean circulation in the early 21st century. Progress in Oceanography 146, 142-158.

Dale, B., 1996. Dinoflagellate cyst ecology: modeling and geological applications. In: J. Jansonius and D.C. McGregor (Editors), Palynology: principles and applications, Vol. 3. AASP Foundation, Salt Lake City, 1249-1275.

Dansgaard, W., Johnsen, S. J., Clausen, H. B., Dahl-Jensen, D., Gundestrup, N. S., Hammer, C. U., Hvidberg, C. S., Steffensen, J. P., Sveinbjörnsdottir, A. E., Jouzel, J., Bond, G., 1993. Evidence for general instability of past climate from a 250-kyr ice-core record. Nature 364, 218-220.

de Vernal, A., Harland, R., 1992. Quaternary organic-walled dinoflagellate cysts of the North Atlantic Ocean and adjacent seas: ecostratigraphy and biostratigraphy. In "Neogene and Quaternary Dinoflagellate Cyst of the North Atlantic Ocean and Adjacent Seas: Ecostratigraphy and Biostratigraphy" (M. J. Head and J. H. Wrenn, Eds.), pp. 289328. American Association of Stratigraphic Palynologists Foundation, Dallas.

de Vernal, A., Henry, M., Bilodeau, G., 1999. Technique de préparation et d'analyse en micropaléontologie. Les Cahiers du GEOTOP vol. 3, Université du Québec à Montréal, Montréal, Canada.

de Vernal, A., Hillaire-Marcel, C., Turon, J.-L., Matthiessen, J., 2000. Reconstruction of seasurface temperature, salinity, and sea-ice cover in the northern North Atlantic during the last glacial maximum based on dinocyst assemblages. Can. J. Earth Sci. 37, 725750.

de Vernal, A., Hillaire-Marcel, C., Peltier, W.R., Weaver, A.J., 2002. The structure of the upper water column in the northwest North Atlantic: modern vs. Last Glacial Maximum conditions. Paleoceanography 17, 1050.

de Vernal, A., Eynaud, F., Henry, M., Hillaire-Marcel, C., Londeix, L., Mangin, S., Matthiessen, J., Marret, F., Radi, T., Rochon, A., Solignac, S., Turon, J.-L., 2005. Reconstruction of sea-surface conditions at middle to high latitudes of the Northern Hemisphere during the Last Glacial Maximum (LGM) based on dinoflagellate cyst assemblages. Quat. Sci. Rev. 24, 897-924. 
de Vernal, A., Rosell-Melé, A., Kucera, M., Hillaire-Marcel, C., Eynaud, F., Weinelt, M., Dokken, T., Kageyama, M., 2006. Comparing proxies for the reconstruction of LGM sea-surface conditions in the northern North Atlantic. Quat. Sci. Rev. 25, 2820-2834.

de Vernal, A., Radi, T., Zaragosi, S., Van Nieuwenhove, N., Rochon, A., Allan, E., et al., 2020. Distribution of common modern dinoflagellate cyst taxa in surface sediments of the Northern Hemisphere in relation to environmental parameters: The new $n=1968$ database. Mar. Micropaleontol. 101796.

Denton, G.H., Alley, R.B., Comer, G.C., Broecker, W.S., 2005. The role of seasonality in abrupt climate change. Quat. Sci. Rev. 24, 1159-1182.

Denton, G.H., Anderson, R.F., Toggweiler, J.R., Edwards, R.L., Schaefer, J.M., Putnam, A.E., 2010. The last glacial termination. Science 328, 1652-1656.

Deschamps, P., Durand, N., Bard, E., Hamelin, B., Camoin, G., Thomas, A. L., et al., 2012. Ice-sheet collapse and sea-level rise at the Bølling warming 14,600 years ago. Nature $483,559-564$.

Ehlers, J., Gibbard, P.L., Hughes, P.D., 2011. Quaternary Glaciations e Extent and Chronology, vol. 15. Elsevier, Amsterdam, pp. 1126.

Eynaud, F., 1999. Kystes de dinoflagelle's et evolution paléoclimatique et paléohydrologique de l'Atlantique Nord au cours du Dernier Cycle Climatique du Quaternaire, Ph.D. thesis, 291 pp. Univ. of Bordeaux 1, Bordeaux, France.

Eynaud, F., Turon, J. L., Duprat, J., 2004. Comparison of the Holocene and Eemian palaeoenvironments in the South Icelandic Basin: dinoflagellate cysts as proxies for the North Atlantic surface circulation. Rev. Palaeobot. Palynol. 128, 55-79.

Eynaud, F., Zaragosi, S., Scourse, J.D., Mojtahid, M., Bourillet, J.F., Hall, I.R., Penaud, A., Locascio, M., Reijonen, A., 2007. Deglacial laminated facies on the NW European continental margin: the hydrographic significance of British Ice sheet deglaciation and Fleuve Manche paleoriver discharges. Geochem. Geophys. Geosyst. 8, Q06019.

Eynaud, F., De Abreu, L., Voelker, A., Schönfeld, J., Salgueiro, E., Turon, J. L., et al., 2009. Position of the Polar Front along the western Iberian margin during key cold episodes of the last $45 \mathrm{ka}$. Geochem. Geophys. Geosyst. 10, Q07U05.

Eynaud, F., Malaizé, B., Zaragosi, S., de Vernal, A., Scourse, J., Pujol, C., et al., 2012. New constraints on European glacial freshwater releases to the North Atlantic Ocean. Geophys. Res. Lett. 39.

Eynaud, F., Londeix, L., Penaud, A., Sanchez-Goni, M. F., Oliveira, D., Desprat, S., Turon, J. L., 2016. Dinoflagellate cyst population evolution throughout past interglacials: Key 
features along the Iberian margin and insights from the new IODP Site U1385 (Exp 339). Glob. Planet. Chang. 136, 52-64.

Fensome, R. A., Williams, G. L., 2004. The Lentin and Williams index of fossil dinoflagellates, 2004 edition. In: AASP Foundation Contributions Series 42, pp. 909.

Fletcher, W.J., Sanchez Goñi, M.F., 2008. Orbital- and sub-orbital-scale climate impacts on vegetation of the western Mediterranean basin over the last 48,000 yr. Quat. Res. 70, $451-464$.

Ganne A., Leroyer C., Penaud A., Mojtahid M., 2016. Present-day palynomorph deposits in an estuarine context: the case of the Loire Estuary. Journal of Sea Research 118, 3551.

Genty, D., Blamart, D., Ghaleb, B., Plagnes, V., Causse, C., Bakalowicz, M., Zouari, K., Chkir, N., Hellstrom, J., Wainer, K., Bourges, F., 2006. Timing and dynamics of the last deglaciation from European and North African d13C stalagmite profiles of comparison with Chinese and South Hemisphere stalagmites. Quat. Sci. Rev. 25, 2118-2142.

Gibbard, P. L., 1988. The history of the great northwest European rivers during the past three million years. Philosophical Transactions of the Royal Society of London. B, Biological Sciences 318, 559-602.

Grousset, F.E., Pujol, C., Labeyrie, L., Auffret, G., Boelaert, A., 2000. Were the North Atlantic Heinrich events triggered by the behaviour of the European ice sheets? Geology 28, 123-126.

Grousset, F.E., Cortijo, E., Herve, L., Richter, T., Burdloff, D., Duprat, J.,Weber, O., 2001. Zooming in on Heinrich layers. Paleoceanography 16, 240-259.

Guiot, J., de Vernal, A., 2007. Transfer functions: methods for quantitative paleoceanography based on microfossils. In: Hillaire-Marcel (Ed.), Proxies in Late Cenozoic Paleoceanography. Developments in Marine Geology 1. Elsevier, pp. 523-563.

Hall, I.R., Moran, S.B., Zahn, R., Knutz, P.C., Shen, C.-C., Edwards, R.L., 2006. Accelerated drawdown of meridional overturning in the late-glacial Atlantic triggered by transient pre-H event freshwater perturbation. Geophys. Res. Lett. 33, L16616.

Hammer, Ø., Harper, D. A., Ryan, P. D., 2001. PAST: Paleontological statistics software package for education and data analysis. Palaeontologia electronica 4, 9.

Harland, R., 1983. Distribution maps of Recent dinoflagellate cysts in bottom sediments from the North Atlantic Ocean and adjacent seas. Palaeontology 26, 321-387. 
1044 Harper, D. A., 1999. Numerical palaeobiology: computer-based modelling and analysis of fossils and their distributions. John Wiley \& Sons Inc.

1046

1047

1048

1049

1050

1051

1052

1053

1054

1055

1056

1057

1058

1059

1060

1061

1062

1063

1064

1065

1066

1067

1068

1069

1070

1071

1072

1073

1074

1075

1076

Harrison, S. P., Goñi, M. S., 2010. Global patterns of vegetation response to millennial-scale variability and rapid climate change during the last glacial period. Quaternary Science Reviews 29, 2957-2980.

Heinrich, H.,1988. Origin and consequences of cyclic ice rafting in the Northeast Atlantic Ocean during the past 130,000 years. Quat. Res. 29, 142-152.

Hemming, S.R., Bond, G.C., Broecker, W.S., Sharp, W.D., Klas-Mendelson, M., 2000. Evidence from ${ }^{40} \mathrm{Ar} /{ }^{39} \mathrm{Ar}$ ages of individual hornblende grains for varying Laurentide sources of iceberg discharges 22,000 to 10,500 yr B.P. Quat. Res. 54, 372-383.

Hemming, S.R., 2004. Heinrich events: massive late Pleistocene detritus layers of the North Atlantic and their global climate imprint. Rev. Geophys. 42, RG1005, 1-43.

Hodell, D., Crowhurst, S., Skinner, L., Tzedakis, P. C., Margari, V., Channell, J. E., et al., 2013. Response of Iberian Margin sediments to orbital and suborbital forcing over the past 420 ka. Paleoceanography 28, 185-199.

Hodell, D. A., Nicholl, J. A., Bontognali, T. R., Danino, S., Dorador, J., Dowdeswell, J. A., et al., 2017. Anatomy of Heinrich Layer 1 and its role in the last deglaciation. Paleoceanography 32, 284-303.

Ivanovic, R. F., Gregoire, L. J., Burke, A., Wickert, A. D., Valdes, P. J., Ng, H. C., et al., 2018. Acceleration of northern ice sheet melt induces AMOC slowdown and northern cooling in simulations of the early last deglaciation. Paleoceanography and Paleoclimatology 33, 807-824.

Jalut, G., Turu i Michels, V., Dedoubat, J.J., Otto, T., Ezquerra, J., Fontugne, M., Belet, J.M., Bonnet, L., García de Celis, A., Redondo-Vega, J.M., Vidal-Romaní, J.R., Santos, L., 2010. Palaeoenvironmental studies in NW Iberia (Cantabrian range): vegetation history and synthetic approach of the last deglaciation phases in the western Mediterranean. Palaeogeogr. Palaeoclimatol. Palaeoecol. 297, 330-350.

Kaiser, J., 2001. Caractérisation palynologique des flux terrigènes Manche-Golfe de Gascogne au cours du Dernier Maximum Glaciaire et du réchauffement Holocène. Maîtrise des Sciences de l'Environnement, Univ. Bordeaux 1, Bordeaux, France, 30 pp.

Kempama, E.W., Reimnitz, E., Barnes, P.W., 2001. Anchor-ice formation and ice rafting in southwestern Lake Michigan, U.S.A. Journal of Sedimentary Research 71, 346-354. 
1077

1078

1079

1080

1081

1082

1083

1084

1085

1086

1087

1088

1089

1090

1091

1092

1093

1094

1095

1096

1097

1098

1099

1100

1101

1102

1103

1104

1105

1106

1107

1108

1109

Knutz, P.C., Austin, W.E.N., Jones, E.J.W., 2001. Millennial-scale depositional cycles related to British Ice Sheet variability and North Atlantic paleocirculation since $45 \mathrm{yr}$ B. P., Barra Fan, U. K. margin. Paleoceanography 16, 53-64.

Knutz, P.C., Zahn, R., Hall, I.R., 2007. Centennial-scale variability of the British Ice Sheet: implications for climate forcing and Atlantic meridional overturning circulation during the last deglaciation. Paleoceanography 22, PA1207.

Kucera, M., Weinelt, M., Kiefer, T., Pflaumann, U., Hayes, A., Weinelt, M., et al., 2005. Reconstruction of sea-surface temperatures from assemblages of planktonic foraminifera: multi-technique approach based on geographically constrained calibration data sets and its application to glacial Atlantic and Pacific Oceans. Quat. Sci. Rev. 24, 951-998.

Lambeck, K., Rouby, H., Purcell, A., Sun, Y., Sambridge, M., 2014. Sea level and global ice volumes from the Last Glacial Maximum to the Holocene. Proceedings of the National Academy of Sciences 111, 15296-15303.

Lambert C., Vidal M., Penaud A., Combourieu-Nebout N., Lebreton V., Ragueneau O., Gregoire G., 2017. Modern palynological record in the Bay of Brest (NW France): Signal calibration for palaeo-reconstructions. Rev. Palaeobot. Palynol. 244, 13-25.

Lewis, J., Dodge, J. D., Powell, A. J., 1990. Quaternary dinoflagellate cysts from the upwelling system off shore Peru, Hole 686B, ODP leg 112. Proceedings of ODP Scientific Results, 112, 323-327.

Lézine, A.M., Duplessy, J.C., Cazet, J.P., 2005. West African monsoon variability during the last deglaciation and the Holocene: evidence from fresh water algae, pollen and isotope data from core KW31, Gulf of Guinea. Palaeogeogr. Palaeoclimatol. Palaeoecol 219, 225-237.

Marcott, S. A., Clark, P. U., Padman, L., Klinkhammer, G. P., Springer, S. R., Liu, Z., et al., 2011. Ice-shelf collapse from subsurface warming as a trigger for Heinrich events. Proceedings of the National Academy of Sciences 108, 13415-13419.

Margalef, R., 1958. Temporal succession and spatial heterogeneity in phytoplankton. Perspectives in marine biology 323-349.

Marret, F., 1994.Distribution of dinoflagellate cysts in recent marine sediments from the east Equatorial Atlantic (Gulf of Guinea). Rev. Palaeobot. Palynol. 84, 1-22.

Marret, F., Zonneveld, K.A.F., 2003. Atlas of modern organic-walled dinoflagellate cyst distribution. Rev. Palaeobot. Palynol. 125, 1-200. 
Marret, F., Scourse, J., Austin, W., 2004. Holocene shelf-sea seasonal stratification dynamics: A dinoflagellate cyst record from the Celtic Sea, NW European shelf. The Holocene 14, 689-696.

Marret, F., Bradley, L., de Vernal, A., Hardy, W., Kim, S. Y., Mudie, P., et al., 2020. From bi-polar to regional distribution of modern dinoflagellate cysts, an overview of their biogeography. Marine Micropaleontology 159, 101753.

Martrat, B., Grimalt, J. O., Shackleton, N. J., de Abreu, L., Hutterli, M. A., Stocker, T. F., 2007. Four climate cycles of recurring deep and surface water destabilizations on the Iberian margin. Science 317, 502-507.

Martrat, B., Jimenez-Amat, P., Zahn, R., Grimalt, J. O., 2014. Similarities and dissimilarities between the last two deglaciations and interglaciations in the North Atlantic region. Quat. Sci. Rev. 99, 122-134.

Matthiessen, J., 1995. Distribution patterns of dinoflagellate cysts and other organic-walled microfossils in recent Norwegian-Greenland Sea sediments. Mar. Micropaleontol. 24, $307-334$.

McManus, J.F., Francois, R., Gherardi, J.M., Keigwin, L.D., Drown-Leger, S., 2004. Collapse and rapid resumption of Atlantic meridional circulation linked to deglacial climate changes. Nature 428, 834-837.

Ménot, G., Bard, E., Rostek, R., Weijers, W.H., Hopmans, E.C., Schouten, S., Sinninghe Damsté, J.S., 2006. Early reactivation of European rivers during the last deglaciation. Science 313, 1623-1625.

Missiaen, L., Waelbroeck, C., Pichat, S., Jaccard, S. L., Eynaud, F., Greenop, R., Burke, A. 2019. Improving North Atlantic marine core chronologies using ${ }^{230} \mathrm{Th}$ normalization. Paleoceanography and paleoclimatology 34, 1057-1073.

Mix, A.C., Bard, E., Schneider, R., 2001. Environmental processes of the ice age: land, oceans, glaciers (EPILOG). Quat. Sci. Rev. 20 (4), 627-657.

Mojtahid, M., Eynaud, F., Zaragosi, S., Scourse, J., Bourillet, J.F., Garlan, T., 2005. Palaeoclimatology and palaeohydrography of the glacial stages on Celtic and Armorican margins over the last 360000 yrs. Marine Geology 224, 57-82.

Mojtahid, M., Toucanne, S., Fentimen, R., Barras, C., Le Houedec, S., Soulet, G., et al., 2017. Changes in northeast Atlantic hydrology during Termination 1: Insights from Celtic margin's benthic foraminifera. Quaternary Science Reviews 175, 45-59. 
1142

1143

1144

1145

1146

1147

1148

1149

1150

1151

1152

1153

1154

1155

1156

1157

1158

1159

1160

1161

1162

1163

1164

1165

1166

1167

1168

1169

1170

1171

1172

1173

1174

1175

Morellón, M., Valero-Garcés, B., Vegas-Vilarrúbia, T., González-Sampériz, P., Romero, Ó., et al., 2009. Late glacial and Holocene palaeohydrology in the western Mediterranean region: The Lake Estanya record (NE Spain). Quat. Sci. Rev. 28, 2582-2599.

Moreno, A., Stoll, H.M., Jimenez-Sanchez, M., Cacho, I., Valero-Garces, B., Ito, E., Edwards, L.R., 2010. A speleothem record of rapid climatic shifts during last glacial period from Northern Iberian Peninsula. Glob. Planet. Chang. 71, 218-231

Morzadec-Kerfourn, M.-T., 1977. Les kystes de Dinoflagellés dans les sédiments récents le long des côtes bretonnes. Rev. Micropaleontol. 20, 157-166.

National Oceanographic Data Centre (NODC), 2001. World Ocean Atlas. http://www.nodc.noaa.gov/OC5/WODOl/pr_wodOl.html.

Naughton, F., Sanchez Goñi, M.F., Desprat, S., Turon, J.-L., Duprat, J., Malaizé, B., Joli, C., Cortijo, E., Drago, T., Freitas, M.C., 2007. Present-day and past (last 25000 years) marine pollen signal off western Iberia. Mar. Micropaleontol. 62, 91-114.

Naughton, F., Sanchez Goñi, M.F., Kageyama, M., Bard, E., Cortijo, E., Desprat, S., Duprat, J., Malaizé, B., Joli, C., Rostek, F., Turon, J.-L., 2009. Wet to dry climatic trend in north western Iberia within Heinrich events. Earth Planet. Sci. Lett. 284, 329-342.

Naughton, F., Goñi, M. S., Rodrigues, T., Salgueiro, E., Costas, S., Desprat, S., et al., 2016. Climate variability across the last deglaciation in NW Iberia and its margin. Quaternary International 414, 9-22.

Ng, H. C., Robinson, L. F., McManus, J. F., Mohamed, K. J., Jacobel, A. W., Ivanovic, R. F., Gregoire, L.J., Chen, T., 2018. Coherent deglacial changes in western Atlantic Ocean circulation. Nature communications 9, 1-10.

North Greenland Ice Core Project, m., 2004. High-resolution record of Northern Hemisphere climate extending into the last interglacial period. Nature 431, 147-151.

Nygård, A., Sejrup, H.P., Haflidason, H., Lekens, W.A.H., Clark, C.D., Bigg, G.R., 2007. Extreme sediment and ice discharge from marine-based ice streams: new evidence from the North Sea. Geology 35, 395-398.

Peck, V.L., Hall, I.R., Zahn, R., Elderfield, H., Grousset, F., Hemming, S.R., Scourse, J.D., 2006. High resolution evidence for linkages between NW European ice sheet instability and Atlantic Meridional Overturning Circulation. Earth Planet. Sci. Lett. 243, 476-488.

Penaud, A., Eynaud, F., Turon, J.L., Zaragosi, S., Marret, F., Bourillet, J.F., 2008. Interglacial variability (MIS 5 and MIS 7) and dinoflagellate cyst assemblages in the Bay of Biscay (North Atlantic). Mar. Micropaleontol. 68, 136-155. 
Penaud, A., Eynaud, F., Turon, J. L., Zaragosi, S., Malaizé, B., Toucanne, S., Bourillet, J. F. 2009. What forced the collapse of European ice sheets during the last two glacial periods (150 ka BP and 18 ka cal BP)? Palynological evidence. Palaeogeogr. Palaeoclimatol. Palaeoecol. 281, 66-78.

Penaud, A., Eynaud, F., Voelker, L., Helga, A., Turon, J. L., 2016. Palaeohydrological changes over the last $50 \mathrm{ky}$ in the central Gulf of Cadiz: complex forcing mechanisms mixing multi-scale processes. Biogeosciences 13, 5357-5377.

Penaud, A., Ganne, A., Eynaud, F., Lambert, C., Coste, P. O., Herlédan, M., et al., 2020. Oceanic versus continental influences over the last $7 \mathrm{kyrs}$ from a mid-shelf record in the northern Bay of Biscay (NE Atlantic). Quat. Sci. Rev. 229, 106135.

R Development Core Team., 2008. R: A language and environment for statistical computing. R Foundation for Statistical Computing, Vienna, Austria. ISBN 3-900051-07-0.

Radi, T., Bonnet, S., Cormier, M. A., de Vernal, A., Durantou, L., Faubert, É., et al., 2013. Operational taxonomy and (paleo-) autecology of round, brown, spiny dinoflagellate cysts from the Quaternary of high northern latitudes. Mar. Micropaleontol. 98, 41-57.

Rasmussen, S. O., Bigler, M., Blockley, S. P., Blunier, T., Buchardt, S. L., Clausen, H. B., Cvijanovic, I., Dahl-Jensen, D., Johnsen, S. J., et al., 2014. A stratigraphic framework for abrupt climatic changes during the Last Glacial period based on three synchronized Greenland ice-core records: Refining and extending the INTIMATE event stratigraphy, Quat. Sci. Rev. 106, 14-28.

Reimnitz, E., Kempama, E.W., 1987. Field observations of slush-ice generated during freezeup in Artic coastal waters. Mar. Geol. 77, 219-231.

Rochon, A., Vernal, A.d., Turon, J.-L., Matthießen, J., Head, M., 1999. Distribution of recent dinoflagellate cysts in surface sediments from the North Atlantic Ocean and adjacent seas in relation to sea-surface parameters. American Association of Stratigraphic Palynologists Contribution Series 35, 1-146.

Rosell-Melé, A., Comes, P., 1999. Evidence for a Warm Last Glacial Maximum in the Nordic Seas or an example of shortcomings in UK $37^{\prime}$ and UK 37 to estimate low sea surface temperature? Paleoceanography 14, 770-776.

Salgueiro, E., Naughton, F., Voelker, A.H.L., de Abreu, L., Alberto, A., Rossignol, L., Duprat, J., Magalh aes, V.H., Vaqueiro, S., Turon, J.-L., Abrantes, F., 2014. Past circulation along the western Iberian margin: a time slice vision from the Last Glacial to the Holocene. Quat. Sci. Rev. 106, 316-329. 
Stanford, J.D., Rohling, E.J., Hunter, S.E., Roberts, A.P., Rasmussen, S.O., Bard, E., McManus, J., Fairbanks, R.G., 2006. Timing of mwp-1a and climate responses to meltwater injections. Paleoceanography 21, PA4103.

Stanford, J. D., Rohling, E. J., Bacon, S., Roberts, A. P., Grousset, F. E., Bolshaw, M., 2011. A new concept for the paleoceanographic evolution of Heinrich event 1 in the North Atlantic. Quat. Sci. Rev. 30, 1047-1066.

Sutton, R., Allen, M., 1997. Decadal predictability of North Atlantic sea surface temperature and climate. Nature 388, 563-567.

Svensson, A., Andersen, K.K., Bigler, M., Clausen, H.B., Dahl-Jensen, D., Davies, S.M., Johnsen, S.J., Muscheler, R., Rasmussen, S.O., Röthlisberger, R., Steffensen, J.P., Vinther, B.M., 2006. The Greenland ice core chronology 2005, 15-42 ka. Part 2: comparison to other records. Quat. Sci. Rev. 25, 23-24.

Svensson, A., Andersen, K. K., Bigler, M., Clausen, H. B., Dahl- Jensen, D., Davies, S. M., J ohnsen, S. J., Muscheler, R., Parrenin, F., Rasmussen, S. O., Röthlisberger, R., Seierstad, I., Steffensen, J. P., Vinther, B. M., 2008. A 60 000-year Greenland stratigraphic ice core chronology. Clim. Past. 4, 47-57.

Toucanne, S., Zaragosi, S., Bourillet, J.F., Naughton, F., Cremer, M., Eynaud, F., Dennielou, B., 2008. Activity of the turbidite levees of the Celtic-armorican margin (Bay of Biscay) during the last 30,000 years: imprints of the last European deglaciation and Heinrich events. Mar. Geol. 247, 84-103.

Toucanne, S., Zaragosi, S., Bourillet, J.F., Cremer, M., Eynaud, F., Turon, J.L., Fontanier, C. Van Vliet Lanoë, B., Gibbard, P., 2009. Timing of massive 'Fleuve Manche' discharges over the last 350 kyr: insights into the European Ice Sheet oscillations and the European drainage network from MIS 10 to 2. Quat. Sci. Rev. 28, 1238-1256.

Toucanne, S., Zaragosi, S., Bourillet, J. F., Marieu, V., Cremer, M., Kageyama, M., et al., 2010. The first estimation of Fleuve Manche palaeoriver discharge during the last deglaciation: Evidence for Fennoscandian ice sheet meltwater flow in the English Channel ca 20-18 ka ago. Earth Planet. Sci. Lett. 290, 459-473.

Toucanne, S., Zaragosi, S., Bourillet, J. F., Dennielou, B., Jorry, S. J., Jouet, G., Cremer, M. 2012. External controls on turbidite sedimentation on the glacially-influenced Armorican margin (Bay of Biscay, western European margin). Mar. Geol. 303, 137153. 
Toucanne, S., Soulet, G., Freslon, N., Jacinto, R. S., Dennielou, B., Zaragosi, S., et al., 2015. Millennial-scale fluctuations of the European Ice Sheet at the end of the last glacial, and their potential impact on global climate. Quat. Sci. Rev. 123, 113-133.

Toucanne, S., Soulet, G., Vázquez Riveiros, N., Boswell, S. M., Dennielou, B., Waelbroeck, C., ... et al., 2021. The North Atlantic Glacial Eastern Boundary Current as a Key Driver for Ice-Sheet-AMOC Interactions and Climate Instability. Paleoceanography and Paleoclimatology 36, e2020PA004068.

Turon, J. L., 1984. Le palynoplancton dans l'environnement actuel de l'Atlantique Nordoriental. Evolution climatique et hydrologique depuis le dernier maximum glaciaire. Mémoires de l'Institut de Géologie du Bassin d'Aquitaine, 17, 313 pp.

Turon, J.-L., Londeix, L., 1988. Dinoflagellate assemblages in the western Mediterranean, Alboran sea: evidence of the evolution of palaeoenvironments since the last glacial maximum [Les assemblages de kystes de Dinoflagelles en Mediterranee occidentale (Mer d'Alboran): mise en evidence de l'evolution des paleoenvironnements depuis le dernier maximum glaciaire.]. Bulletin - Centres de Recherche Exploration- Production Elf-Aquitaine 12, 313-344.

Turon, J.L., Lézine, A.M., Denèfle, M., 2003. Land-sea correlations for the last glaciation inferred from a pollen and dinocyst record from the Portuguese margin. Quat. Res. 59, $88-96$.

Van Nieuwenhove, N., Pospelova, V., de Vernal, A., Rochon, A., 2020. A historical perspective on the development of the Northern Hemisphere modern dinoflagellate cyst database. 101824.

Versteegh, G. J., Zonneveld, K. A.,1994. Determination of (palaeo-) ecological preferences of dinoflagellates by applying detrended and canonical correspondence analysis to Late Pliocene dinoflagellate cyst assemblages of the south Italian Singa section. Rev. Palaeobot. Palynol. 84, 181-199.

Voelker, A. H., 2002. Global distribution of centennial-scale records for Marine Isotope Stage (MIS) 3: a database. Quat. Sci. Rev. 21, 1185-1212.

Waelbroeck, C., Lougheed, B. C., Riveiros, N. V., Missiaen, L., Pedro, J., Dokken, T., et al., 2019. Consistently dated Atlantic sediment cores over the last 40 thousand years. Scientific data $6,1-12$.

Wall, D., Dale, B., Lohmann, G.P., Smith, W.K., 1977. The environment and climatic distribution of dinoflagellate cysts in modern marine sediments from regions in the north and south Atlantic oceans and adjacent seas. Mar. Micropaleontol. 2, 121-200. 
1275

1276

1277

1278

1279

1280

1281

1282

1283

1284

1285

1286

1287

1288

1289

1290

1291

1292

1293

1294

1295

1296

1297

1298

1299

1300

1301

1302

1303

1304

1305

1306

Wary, M., Eynaud, F., Sabine, M., Zaragosi, S., Rossignol, L., Malaize, B., et al., 2015. Stratification of surface waters during the last glacial millennial climatic events: a key factor in subsurface and deep-water mass dynamics. Clim. Past. 11, 1507.

Weaver, A.J., Saenko, O.A., Clark, P.U., Mitrovica, J.X., 2003. Meltwater pulse 1A from Antarctica as a trigger of the Bølling-Allerød warm interval. Science 299, 1709-1713.

Weinelt, M., Sarnthein, M., Pflaumann, U., Schulz, H., Jung, S., Erlenkeuser, H., 1996. Icefree Nordic Seas during the Last Glacial Maximum? Potential sites of deepwater formation. Paleoclimates 1, 283-309.

Woerther, P., 2013. VT 133 /MERIADZEK cruise, RV Marion Dufresne.

Zaragosi, S., Auffret, G. A., Faugères, J. C., Garlan, T., Pujol, C., Cortijo, E., 2000. Physiography and recent sediment distribution of the Celtic Deep-Sea Fan, Bay of Biscay. Mar. Geol. 169, 207-237.

Zaragosi, S., Eynaud, F., Pujol, C., Auffret, G., Turon, J.-L., Garlan, T., 2001. Initiation of the European deglaciation as recorded in the northwestern Bay of Biscay slope environments (Meriadzek Terrace and Trevelyan Escarpment): a multi-proxy approach. Earth Planet. Sci. Lett. 188, 493-507.

Zaragosi, S., Bourillet, J.F., Eynaud, F., Toucanne, S., Denhard, B., Van Toer, A., Lanfumey, V., 2006. The impact of the last European deglaciation on the deepsea turbidite systems of the Celtic-Armorican margin (Bay of Biscay). Geo-Marine Letters 26, 317-329.

Zonneveld, K.A.F., 1997. New species of organic walled dinoflagellate cysts from modern sediments of the Arabian Sea (Indian Ocean). Rev. Palaeobot. Palynol. 97, 319-337

Zonneveld, K.A.F., Hoek, R.P., Brinkhuis, H., Willems, H., 2001. Geographical distributions of organic-walled dinoflagellate cysts in surficial sediments of the Benguela upwelling region and their relationship to upper ocean conditions. Progress in Oceanography 48, $25-72$.

Zonneveld, K. A., Versteegh, G., Kodrans-Nsiah, M., 2008. Preservation and organic chemistry of Late Cenozoic organic-walled dinoflagellate cysts: A review. Marine Micropaleontology 68, 179-197.

Zonneveld, K.A.F., Marret, F., Versteegh, G.J.M., Bogus, K., Bonnet, S., Bouimetarhan, I., et al., 2013. Atlas of modern dinoflagellate cyst distribution based on 2405 data points Rev. Palaeobot. Palynol. 191, 1-197. 
1307 Zumaque, J., Eynaud, F., de Vernal, A., 2017. Holocene paleoceanography of the Bay of 1308 Biscay: evidence for west-east linkages in the North Atlantic based on dinocyst data. 1309 Palaeogeogr. Palaeoclimatol. Palaeoecol. 468, 403-413. 
Table 1

\begin{tabular}{|c|c|c|c|c|c|c|c|}
\hline $\begin{array}{l}\text { Core } \\
\text { name }\end{array}$ & $\begin{array}{l}\text { Geographic } \\
\text { coordinates } \\
\text { Depth (m) }\end{array}$ & $\begin{array}{l}\text { Dinocyst } \\
\text { assemblages }\end{array}$ & $\begin{array}{l}\text { Ti/Ca- } \\
\text { XRF } \\
\text { ratio }\end{array}$ & $\begin{array}{l}\text { \% } \\
\text { N.pachyderma } \\
\text { s. }\end{array}$ & $\begin{array}{l}\text { IRD } \\
\text { conc } \\
\text { (No g } \\
\text { dry sed) }\end{array}$ & $\begin{array}{l}\text { No } \\
\text { Laminae/cm }\end{array}$ & $\begin{array}{l}\text { BIT index } \\
+\% \text { COT }\end{array}$ \\
\hline $\begin{array}{l}\text { MD13- } \\
\mathbf{3 4 3 8} \\
\text { Studied } \\
\text { core }\end{array}$ & $\begin{array}{l}47^{\circ} 27^{\prime} \mathrm{N} \\
8^{\circ} 27^{\prime} \mathrm{W} \\
2180 \mathrm{~m}\end{array}$ & This study & $\begin{array}{l}\text { S. } \\
\text { Toucanne } \\
\text { in this } \\
\text { study }\end{array}$ & $\begin{array}{l}\text { L. Rossignol } \\
\text { in this study }\end{array}$ & No data & No data & No data \\
\hline $\begin{array}{l}\text { MD95- } \\
\mathbf{2 0 0 2} \\
\text { Reference } \\
\text { core }\end{array}$ & $\begin{array}{l}47^{\circ} 27^{\prime} \mathrm{N} \\
8^{\circ} 32^{\prime} \mathrm{W} \\
2174 \mathrm{~m}\end{array}$ & $\begin{array}{l}\text { Eynaud, } \\
1999 ; \\
\text { Zaragosi et } \\
\text { al., } 2001 \text {; } \\
\text { Eynaud et } \\
\text { al., } 2012\end{array}$ & $\begin{array}{l}\text { Toucanne } \\
\text { et al., } \\
2015\end{array}$ & $\begin{array}{l}\text { Zaragosi et al., } \\
2001 \\
\text { Eynaud et al., } \\
2009\end{array}$ & $\begin{array}{l}\text { Zaragosi } \\
\text { et al., } \\
2001\end{array}$ & $\begin{array}{l}\text { Zaragosi et } \\
\text { al., } 2001\end{array}$ & $\begin{array}{l}\text { Ménot et } \\
\text { al., } 2006\end{array}$ \\
\hline
\end{tabular}


Table 2

\begin{tabular}{|c|c|c|c|}
\hline $\begin{array}{l}\text { Tie points } \\
\text { MD95-2002 }\end{array}$ & $\begin{array}{c}\text { Depth } \\
\text { MD95-2002 (cm) }\end{array}$ & $\begin{array}{l}\text { Equivalent depth } \\
\text { MD13-3438 (cm) }\end{array}$ & $\begin{array}{c}\text { Age cal BP } \\
\text { (Toucanne et al.,2015) }\end{array}$ \\
\hline Top core & 0 & 0 & 1629 \\
\hline End YD & 190 & 126 & 11488 \\
\hline Onset YD & 262 & 170 & 12442 \\
\hline End HS1 & 390 & 242 & 14699 \\
\hline HS1-5 & 455 & 277 & 15908 \\
\hline HS1-4 & 515 & 314 & 16482 \\
\hline HS1-3(2) & 548 & 324 & 16724 \\
\hline HS1-3 & 690 & 428 & 17388 \\
\hline HS1-2 & 745 & 475 & 17559 \\
\hline Onset HS1 & 865 & 567 & 18100 \\
\hline End LGM & 940 & 619 & 18570 \\
\hline LGM-6 & 970 & 640 & 18739 \\
\hline LGM-5 & 1000 & 663 & 18904 \\
\hline LGM-4 & 1040 & 697 & 19127 \\
\hline LGM-3 & 1145 & 788 & 19807 \\
\hline LGM-2 & 1260 & 881 & 21077 \\
\hline LGM-1 & 1340 & 952 & 22788 \\
\hline Onset LGM & 1355 & 960 & 23001 \\
\hline End HS2 & 1375 & 981 & 23185 \\
\hline HS2-4 & 1415 & 1011 & 23560 \\
\hline HS2-3 & 1460 & 1050 & 24249 \\
\hline HS2-2 & 1495 & 1084 & 25031 \\
\hline Onset HS2 & 1550 & 1123 & 26551 \\
\hline End GI-3 & 1573 & 1155 & 27186 \\
\hline Onset GI-3 & 1593 & 1179 & 27720 \\
\hline $\begin{array}{c}\text { End HS3 / Onset } \\
\text { GI-4 } \\
\end{array}$ & 1640 & 1218 & 28953 \\
\hline mid HS3 & 1695 & 1287 & 30116 \\
\hline Onset HS3 & 1745 & 1339 & 31050 \\
\hline Onset GI-5 & 1793 & 1389 & 32419 \\
\hline Onset-GI-7 & 1858 & 1458 & 35694 \\
\hline End GI-8 & 1880 & 1482 & 36900 \\
\hline $\begin{array}{c}\text { End HS4 / Onset } \\
\text { GI-8 }\end{array}$ & 1906 & 1511 & 37908 \\
\hline mid-HS4 & 1968 & 1575 & 39300 \\
\hline
\end{tabular}


Table 3

\begin{tabular}{|c|c|c|}
\hline & Name of taxa & Abbreviation \\
\hline \multirow{22}{*}{$\begin{array}{l}\text { Autotrophic } \\
\text { taxa }\end{array}$} & Bitectatodinium tepikiense & Btep \\
\hline & Impagidinium aculeatum & Iacu \\
\hline & Impagidinium pallidum & Ipal \\
\hline & Impagidinium paradoxum & Ipar \\
\hline & Impagidinium patulum & Ipat \\
\hline & Impagidinium sphaericum & Isph \\
\hline & Lingulodinium machaerophorum & Lmac \\
\hline & Nematosphaeropsis labyrinthus & Nlab \\
\hline & Operculodinium centrocarpum & Ocen \\
\hline & Operculodinium janduchenei & Ojan \\
\hline & Polysphaeridium zoharyi & Pzoh \\
\hline & Spiniferites membranaceus & Smem \\
\hline & Spiniferites delicatus & Sdel \\
\hline & Spiniferites elongatus & Selo \\
\hline & Spiniferites ramosus & Sram \\
\hline & Spiniferites belerius & Sbel \\
\hline & Spiniferites bentorii & Sben \\
\hline & Spiniferites lazus & Slaz \\
\hline & Spiniferites mirabilis & Smir \\
\hline & Spiniferites spp. & Sspp \\
\hline & Spiniferites septentrionalis & Ssep \\
\hline & Cyst of Pentapharsodinium dalei & Pdal \\
\hline \multirow{9}{*}{$\begin{array}{c}\text { Heterotrophic } \\
\text { taxa }\end{array}$} & Islandinium minutum & Imin \\
\hline & Brigantedinium spp. & Bspp \\
\hline & Quinquecuspis spp. & Qspp \\
\hline & Lejeunecysta spp. & Lspp \\
\hline & Dubridinium spp. & Dspp \\
\hline & Votadinium spp. & Vspp \\
\hline & Selenopemphix quanta & Squa \\
\hline & Cyst of Protoperidinium nudum & Pnud \\
\hline & Echinidinium spp. & Espp \\
\hline
\end{tabular}


a)

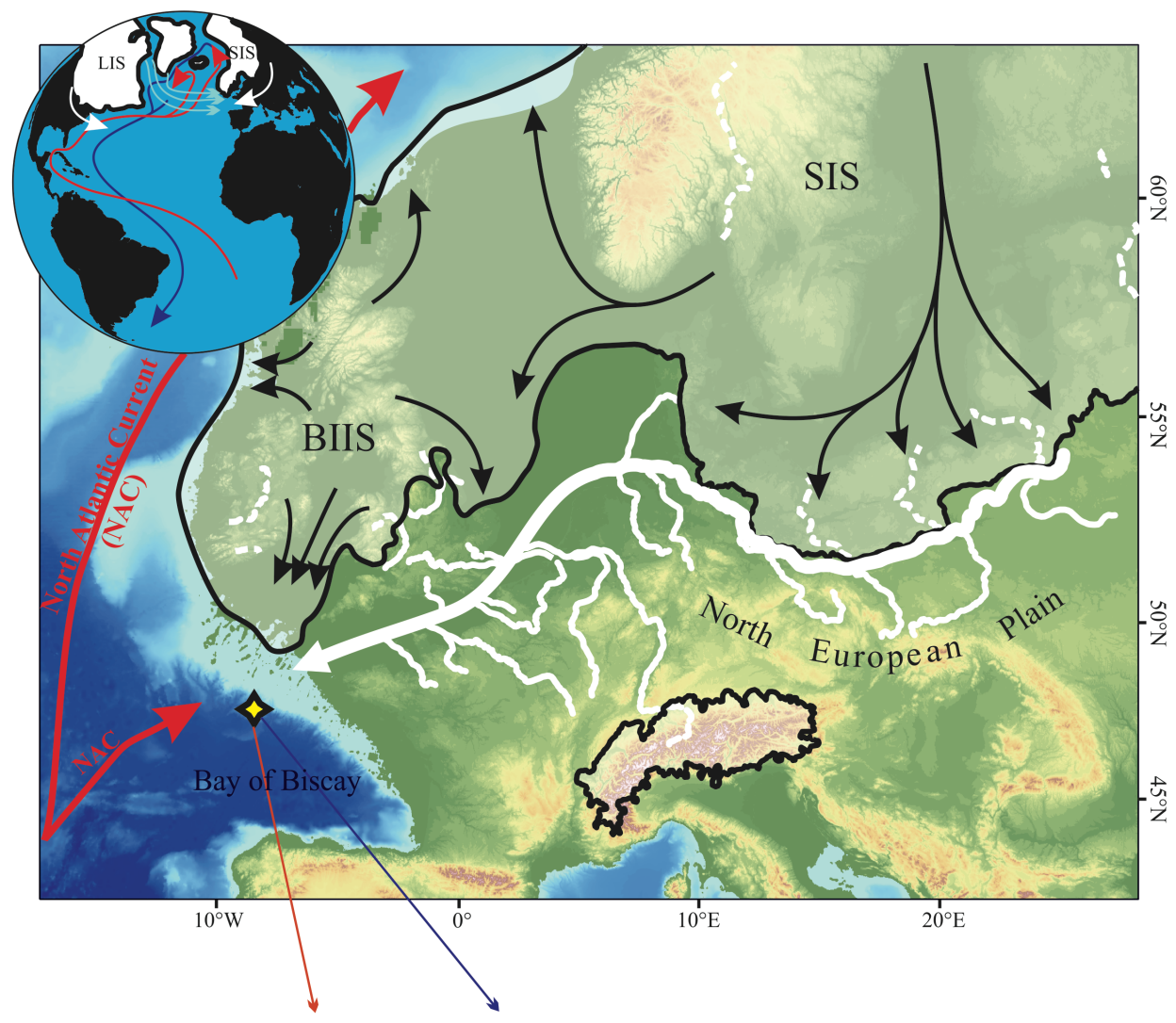

MD95-2002 vs MD13-3438

MD95-2002

CLG. conc.

$\delta^{18}$ O NGRIP (\%) $(G I C C 05 ;$
Svensson et al., 2008) $\begin{array}{ccc}\text { XRF-Ti/Ca } & \% \text { N. pachyderma } & \left(10^{3} \text { No.g dry sed.) }\right. \\ \text { (Toucanne et al., 2015) } & \text { (Zaragosi et al., 2001) } & \text { (Zaragosi et al., 2001) }\end{array}$

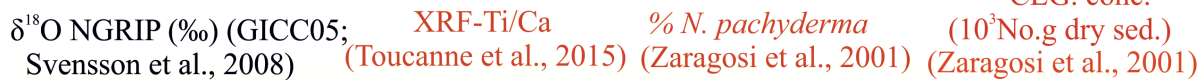

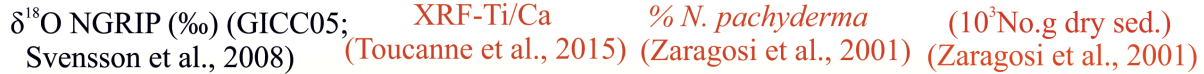

$\begin{array}{llllllllllllllll}0.04 & 0.08 & 0.12 & 0 & 50 & 100 & 0 & 0.5 & 1 & 1.5 & 2 & 0 & 0.2 & 0.4 & 0.6 & 0.8\end{array}$

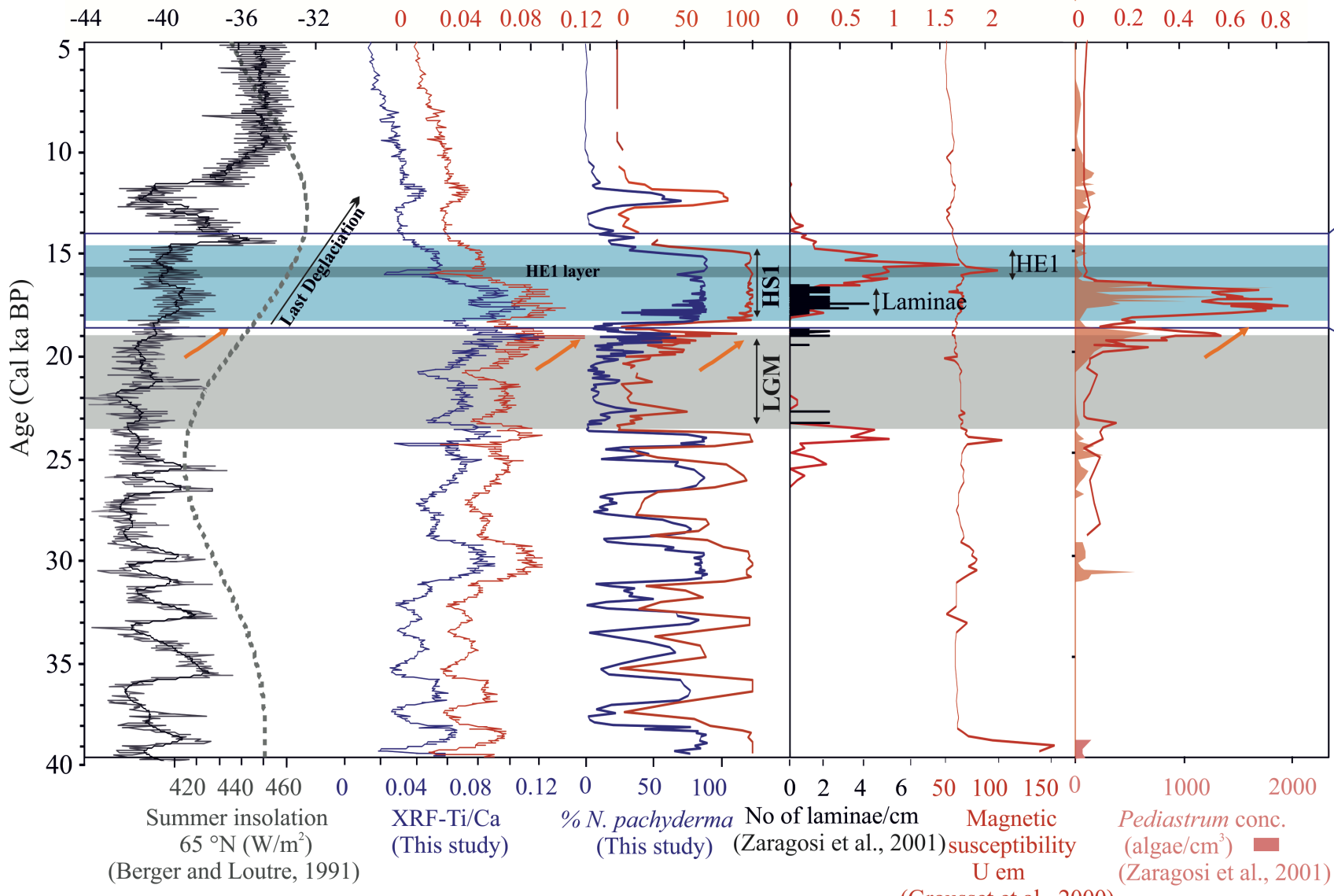

This study * 76 samples

* 58 yrs mean resolution (29 yrs in laminae) 


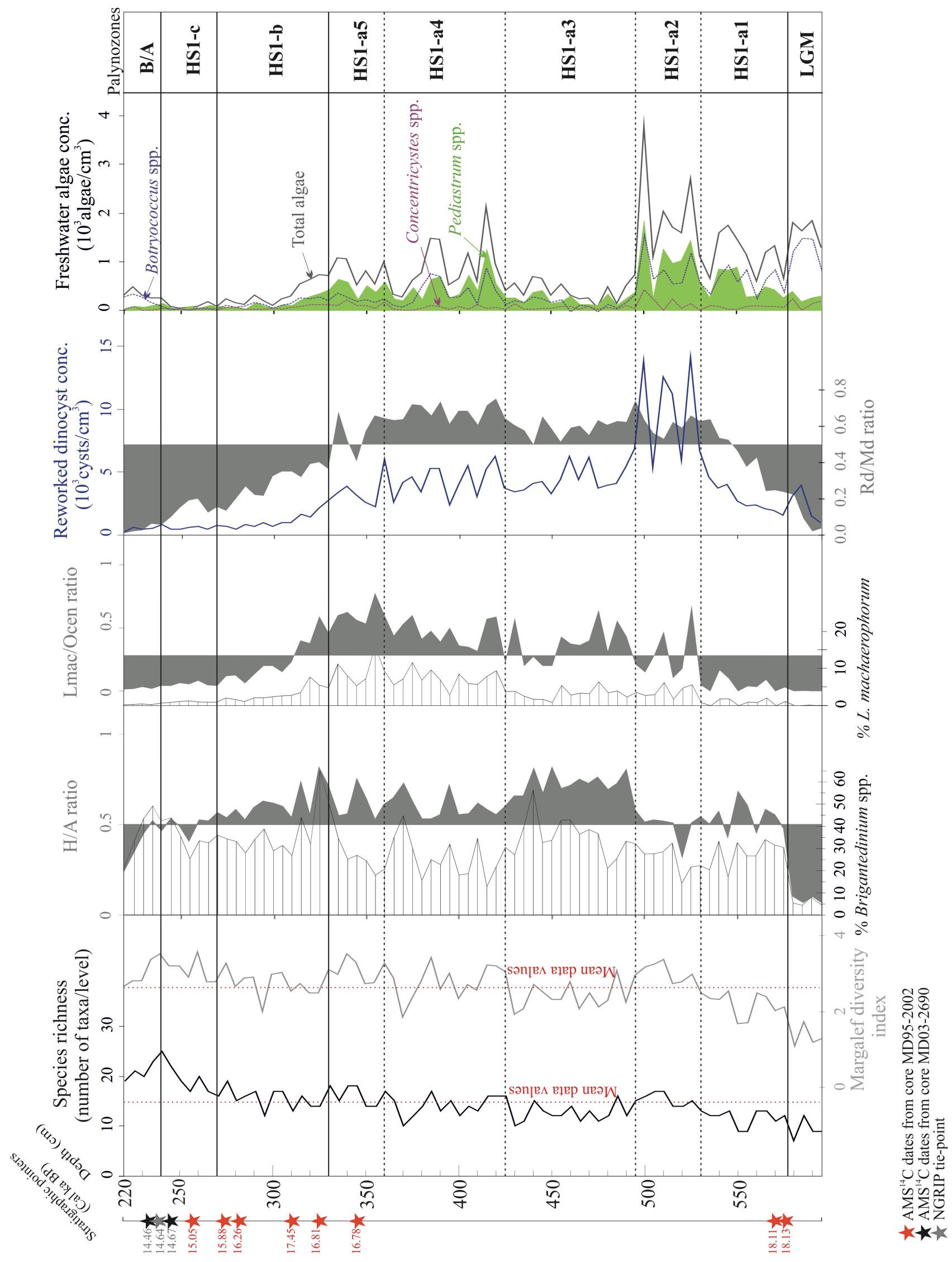




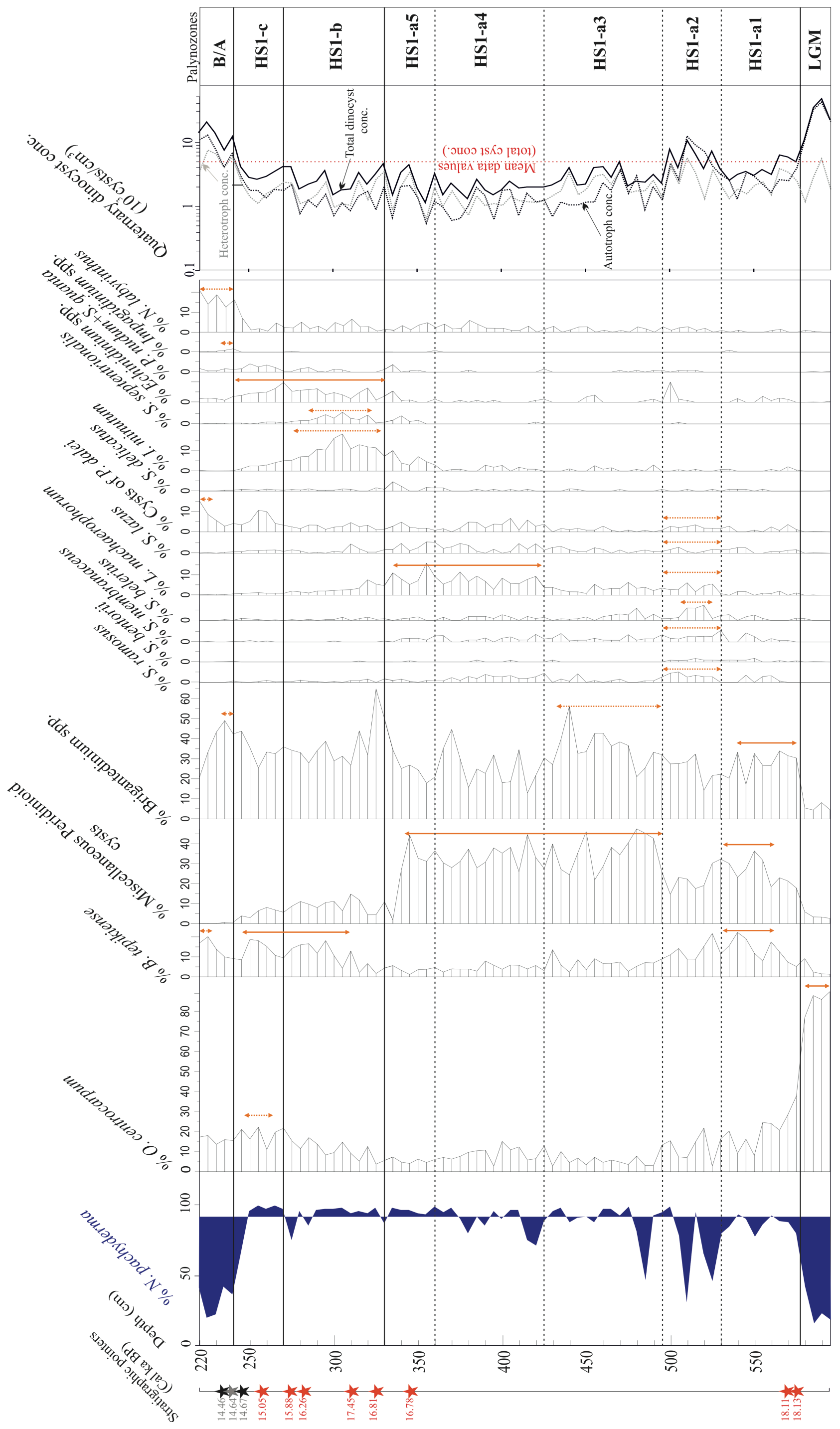

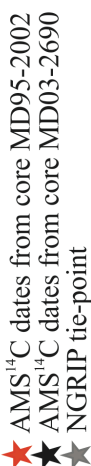


a)

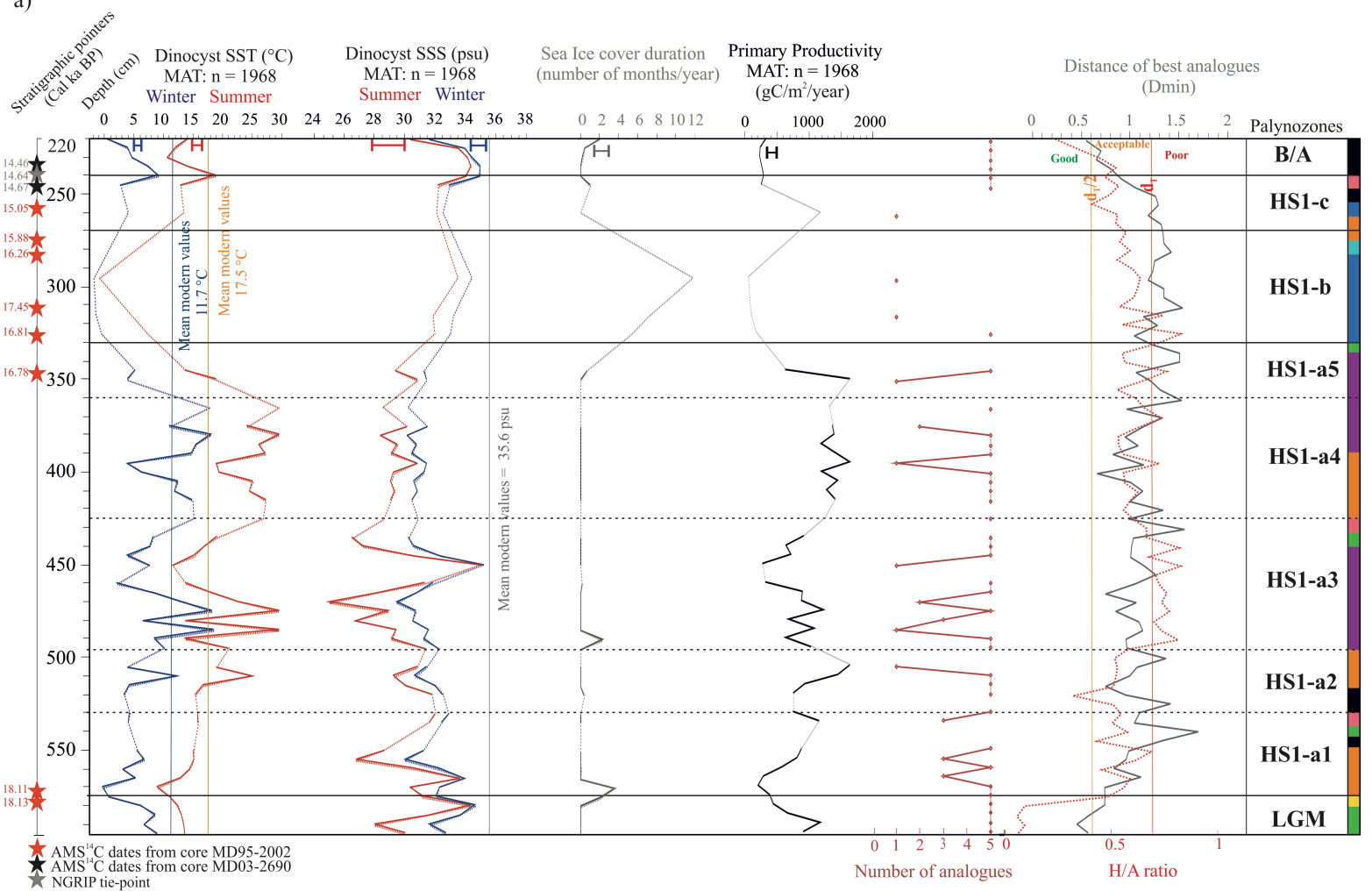

b) Database $n=1968$ (de Vernal et al., 2020)

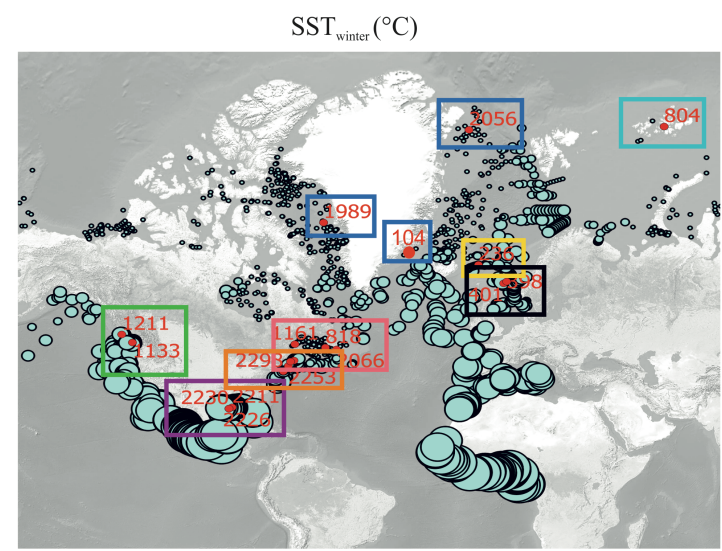

- Analogues found for MD13-3438

Color code corresponding to each geographical sector

Western coasts of Canada

Norwegian Sea

Eastern coasts of Canada

Northeastern coasts of USA

Southeastern coasts of USA

Eastern and Western coasts of Greenland

Svalbard margin

North Sea

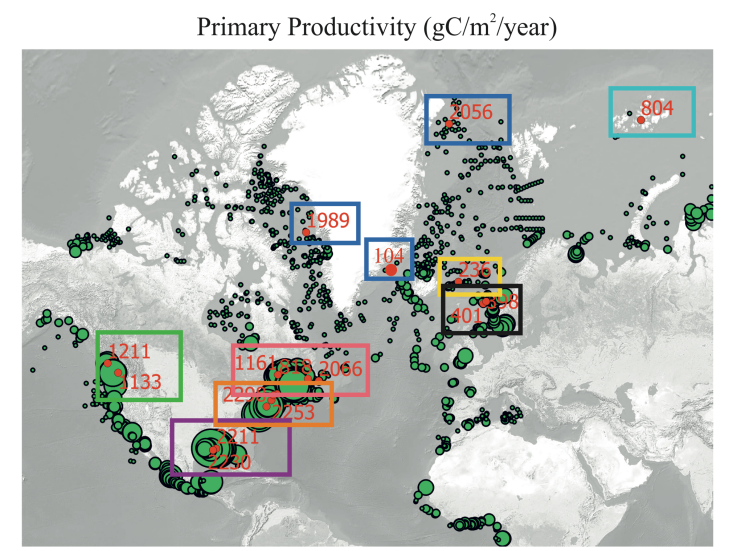

Modern sea-surface mean values of Temperature during winter (SST $_{\text {winter }}$ :blue circles) and Primary Productivity (green circles)
○ $\quad-1.9-1.2$
- $25-224$
$4.3-7.4$
$423-622$
$10.4-13.5$
1019-1218
○ $16.6-19.7$
? $1417-1616$
$25.8-28.9$
1815 - 2014 


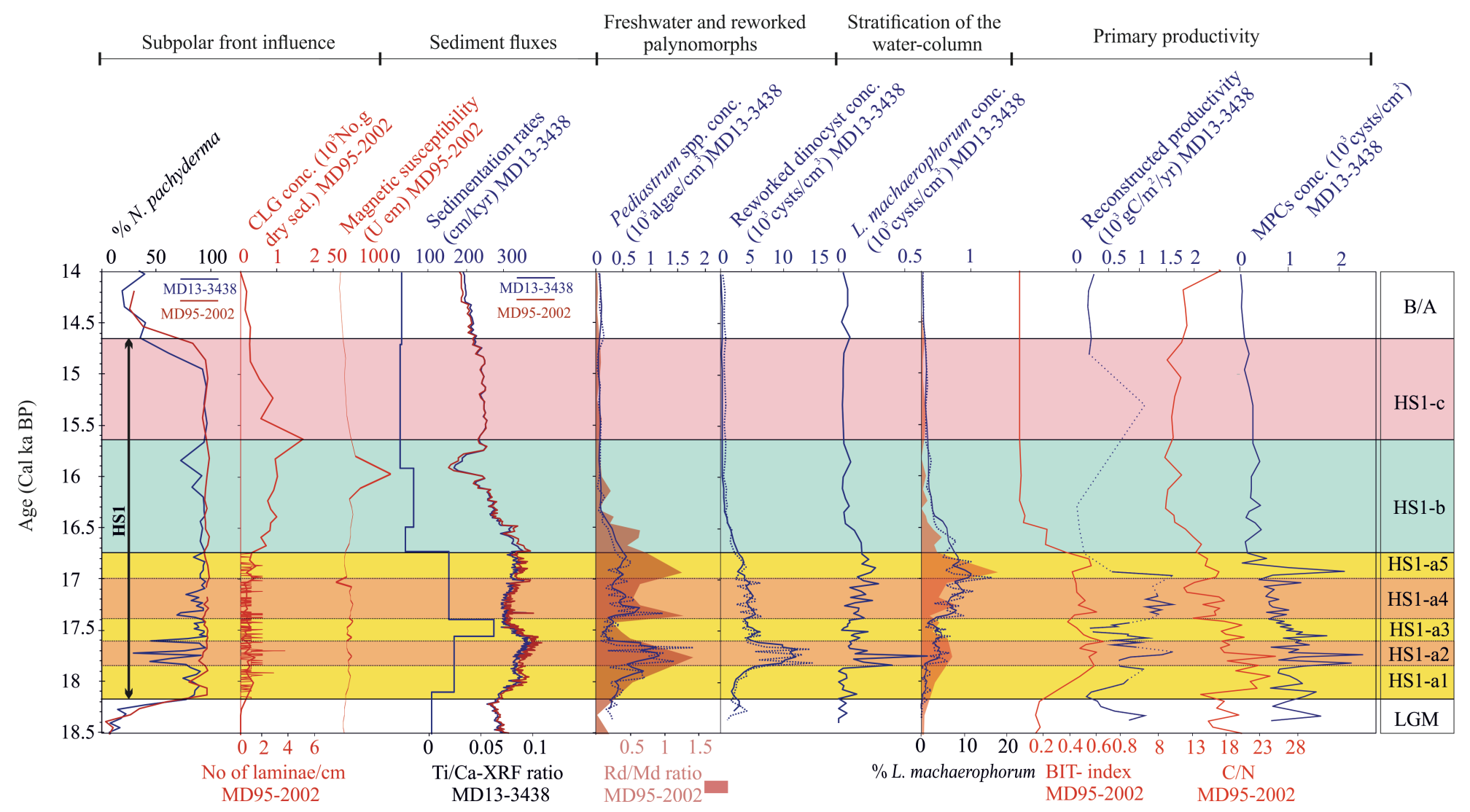




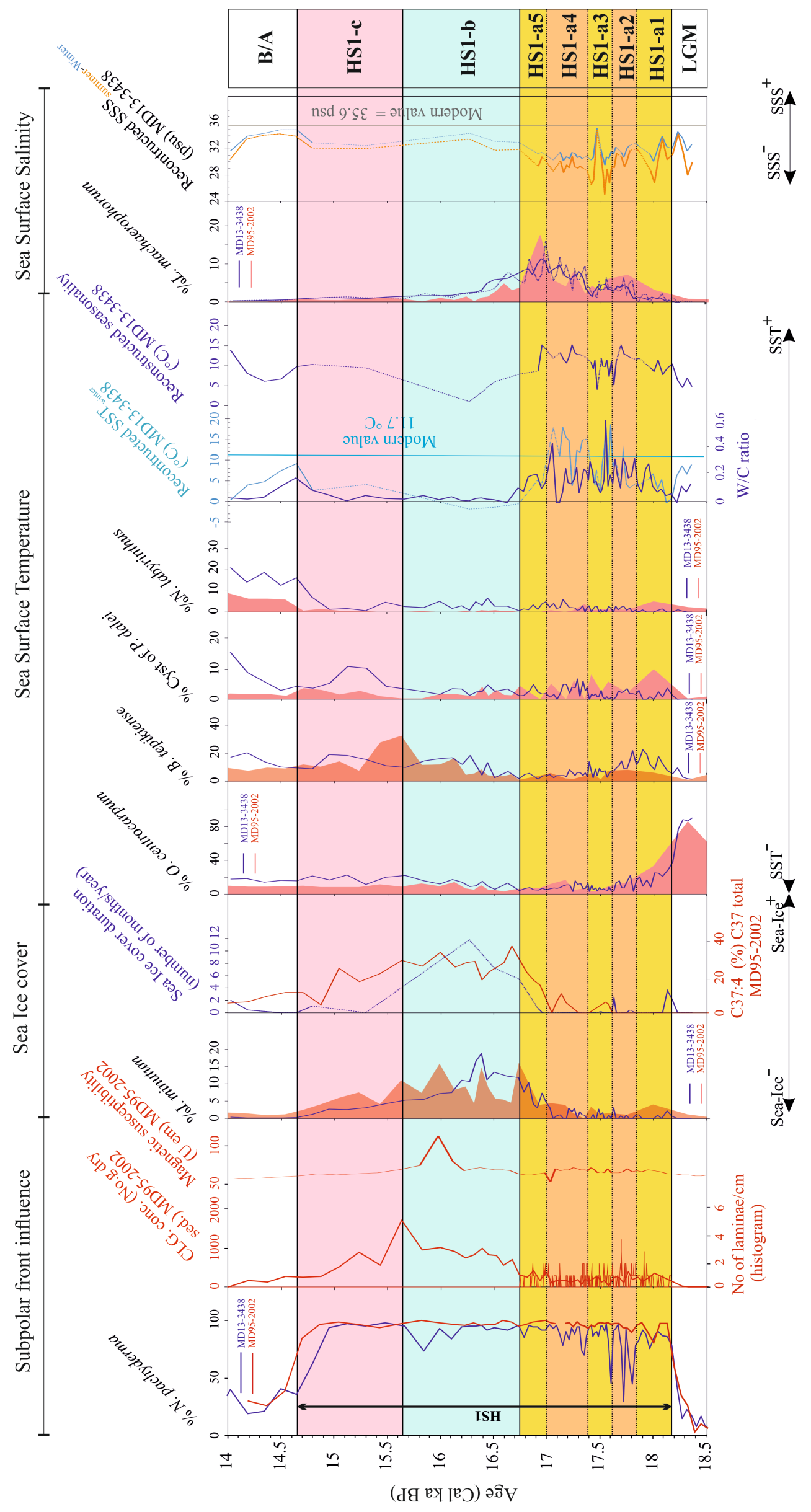




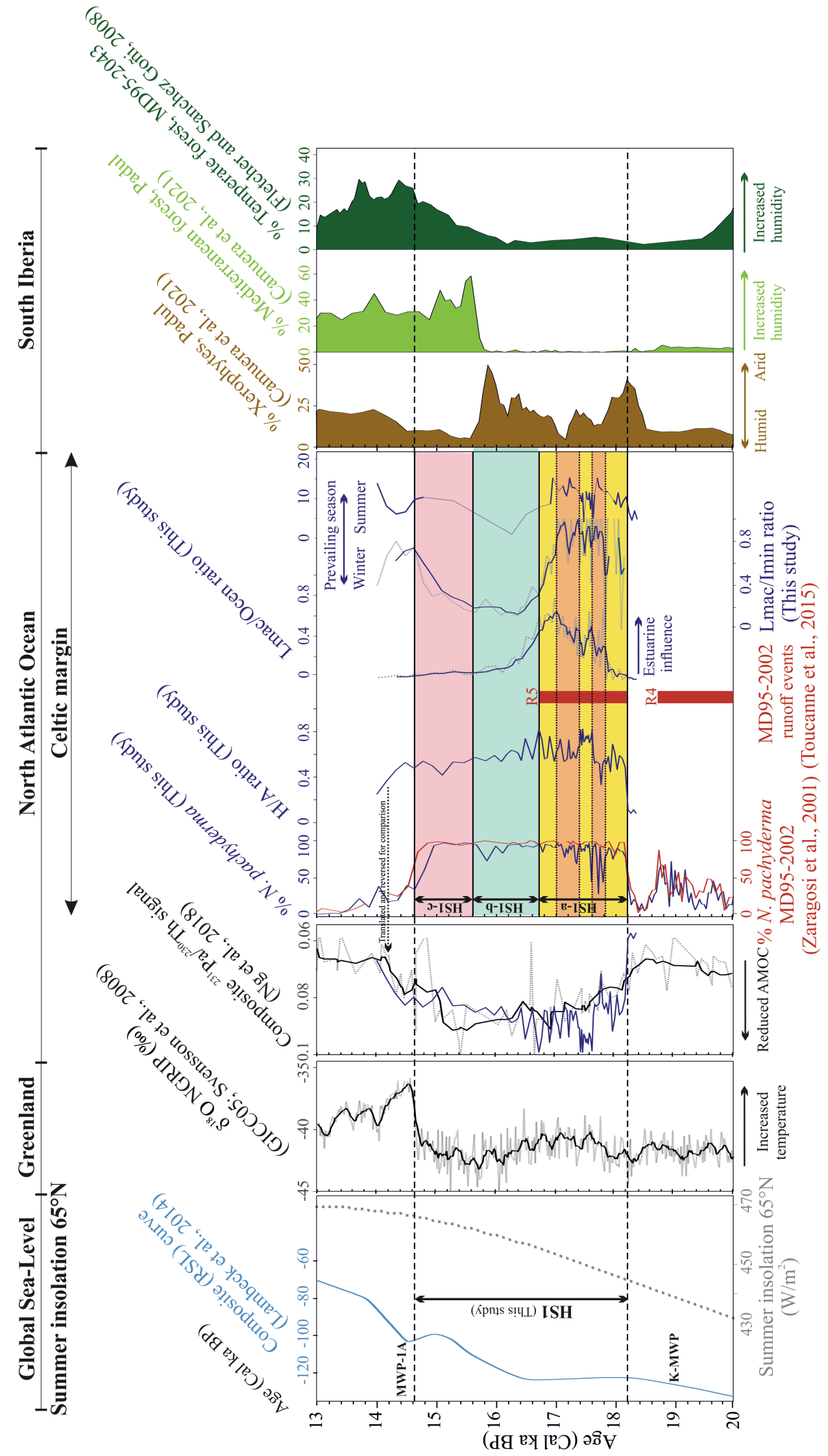




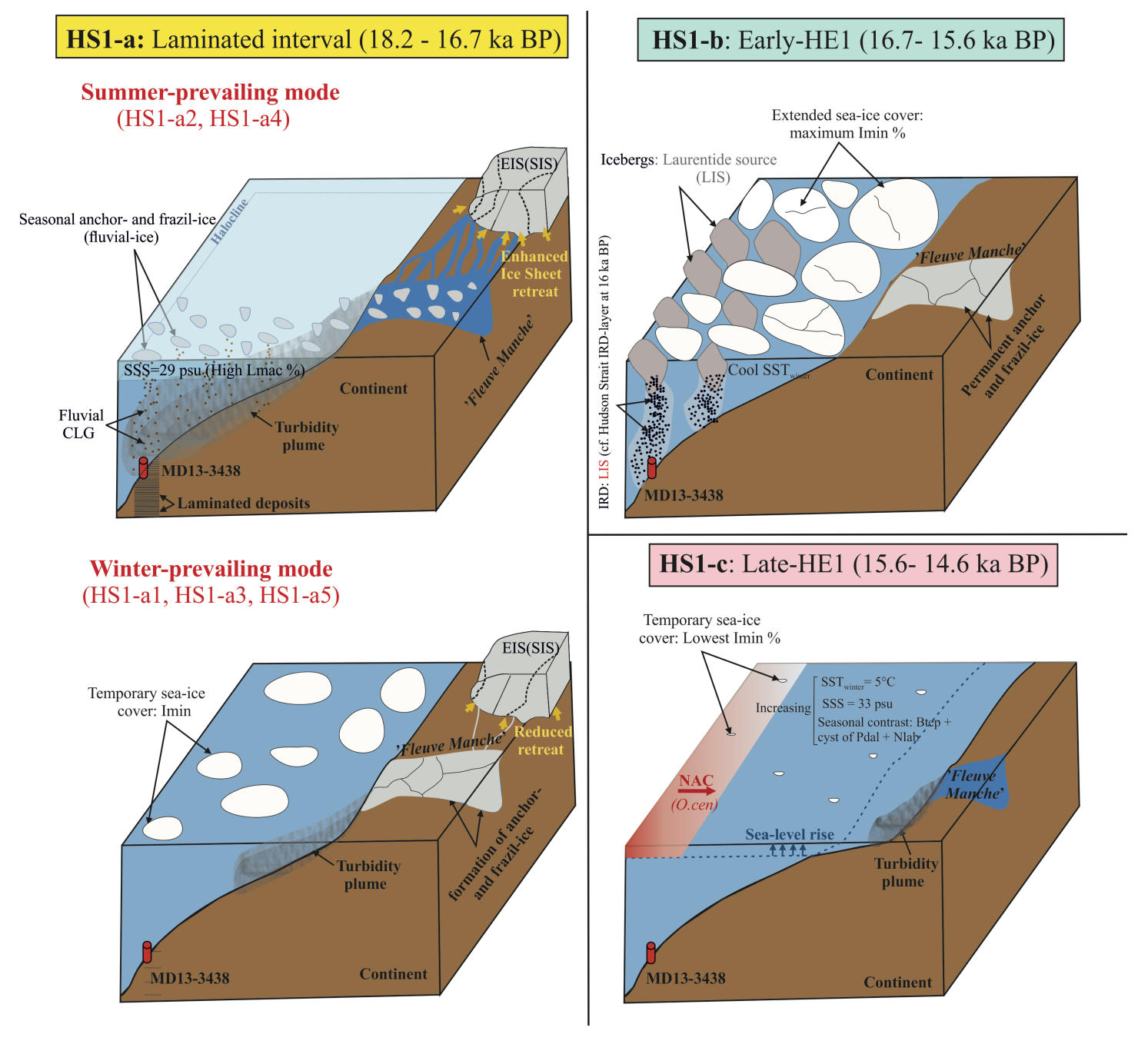

